OPEN ACCESS

Edited by: Zeeda Fatimah Binti Mohamad, University of Malaya, Malaysia

Reviewed by: Matjaž Maletič, University of Maribor, Slovenia Luis Velazquez, Universidad de Sonora, Mexico Giulia Sonetti,

Politecnico di Torino, Italy

*Correspondence: Ingrid Molderez ingrid.molderez@kuleuven.be

Specialty section

This article was submitted to

Sustainable Organizations, a section of the journal

Frontiers in Sustainability

Received: 12 April 2021 Accepted: 20 August 2021 Published: 27 September 2021

Citation:

Molderez I, Baraniuk D and Lambrechts W (2021) The Role of Poetry in Promoting a Sustainability Mindset: Walter Benjamin as a Guide

Toward a Slow Journey.

Front. Sustain. 2:694317.

doi: 10.3389/frsus.2021.694317

\section{The Role of Poetry in Promoting a Sustainability Mindset: Walter Benjamin as a Guide Toward a Slow Journey}

\author{
Ingrid Molderez ${ }^{1 *}$, Diana Baraniuk ${ }^{1}$ and Wim Lambrechts ${ }^{2}$ \\ ${ }^{1}$ Centre for Economics and Sustainable Entrepreneurship (CEDON), KU Leuven Campus Brussels, Brussels, Belgium, \\ ${ }^{2}$ Department of Marketing and Supply Chain Management, Faculty of Management, Open Universiteit, Heerlen, Netherlands
}

The emergence of highly complex sustainability challenges in modern society has led to the necessity of searching for more effective approaches to education for sustainable development. Research has shown that reflection leads toward more profound levels of engagement with respect to sustainable actions. Therefore, higher education has a role to play in stimulating reflection in light of sustainability. Art-based techniques, which have not been included alongside traditional teaching methods, have begun to gain the attention of researchers and teachers in higher education as they produce a deeper impact and involvement and can have a positive influence on the minds and hearts of the students. The aim of this paper is to demonstrate that poetry can contribute to integrating the arts and humanities in management education. The potential effect of poetry on business management majors is being explored as a part of their Corporate Social Responsibility course. Poetry has considerable potential as an innovative approach to teach sustainability, but it is rather unusual in business education. Poetry was chosen as an enabler for reflection and emotions. This original teaching project was followed by a research project relying on reflective assignments. A rereading of Walter Benjamin's Illuminations from the perspective of sustainability studies was a source of inspiration, in particular "Theses on the Philosophy of History," "The Storyteller" and "Unpacking My Library." The paper assumes that Benjamin's ideas relate to a slow journey involving "awakening," "wisdom" and "in a process," three elements that are at the core of promoting a sustainability mindset. The research project consisted of four reflection assignments students had to comply with: reading and interpreting poetry; searching for a poem which would be most appropriate for the discussed sustainability topic; creating their own poem and reflecting on the whole task. The research took place in the second semester of 2020 and first semester of 2021, all in COVID-19 pandemic context. Students' participation was not mandatory, but the majority joined. Their perceptions and impressions reinforce the existing knowledge about the emotional power of poetry to encourage reflection. The results show that poetry plays a relevant role in encouraging future managers to develop a frame of mind that incorporates sustainability and responsibility. Business students are open to this approach because it adds a new and unexpected dimension to their studies. Despite the urge to integrate reflections, 
this is still an exception for the majority of management courses. The results suggest that poetry is a relevant instrument to promote a more sustainable mindset among future managers. Paradoxically, by emphasizing a slow journey, i.e., allowing time for integrating reflective practices, a transition toward sustainability in daily managerial processes can be accelerated.

Keywords: education for sustainable development, poetry, sustainability mindset, reflection, Walter Benjamin, management studies

\section{INTRODUCTION}

Relying on the power of poetry for reflective practices, this paper aims to build a bridge between the arts and humanities on the one hand and the pure instrumental approach of management sciences on the other hand. The paper thereby contributes to the growing demand for integrating arts and humanities in management education by using poetry as a trigger for a sustainability mindset. The sustainability mindset suggested by Kassel et al. (2016) has not been intensely followed up by the study of specific pedagogies to fostering it. This paper will address this research gap and thereby contributing to the urge for an educational transformation.

The issues of sustainability, the greatest challenge humanity as a whole has ever faced before, are acknowledged worldwide. Global sustainability issues, such as of climate change, poverty, loss of biodiversity have been labeled as "super wicked problems," indicating the complexity, uncertainty and urgency of these problems (Levin et al., 2012). A looming threat has been recognized to all three highly interrelated dimensions of sustainable development, i.e., economic, social and environmental. Different action plans have been signed worldwide, like the Paris Agreement in 2016, the seventeen Sustainable Development Goals (SDGs) to be achieved by 2030 (United Nations, 2015), as a follow-up of the eight Millennium Development Goals (United Nations, 2000), the Convention on Biological Diversity. Despite the aims of indivisibility and interconnectedness, the composition of the SDGs lacks integration (Le Blanc, 2015) and is fragmented (Reyers and Selig, 2020). Moreover, no major positive changes have been recorded so far with respect to greenhouse-gas emissions (Victor et al., 2017). IPCC (2018) prefaced its special report on Global Warming with a quote from Antoine de Saint Exupery, translated as "As for the future, it is not about predicting it, but making it possible." In the view of enabling future perspectives, perhaps humanity's best survival strategy lies behind the next generation in general and the paradigm of sustainability education in particular. It is especially crucial for students majoring in business and management as these graduates will be responsible for the companies' policies. Whether they will be committed to sustainable development or not, depends on the quality of the educational system (Mujtaba et al., 2015; Parkes et al., 2017). A holistic approach to learning and teaching sustainability is needed (Hermes and Rimanoczy, 2018), uniting hands, hearts and heads (Shrivastava, 2010). As Hermes and Rimanoczy (2018) argue, sustainability in management education focuses mostly on technical aspects with too little room for reflection and emotions. Building on Nussbaum's (2010) book "Not for profit. Why democracy needs the humanities," we argue that (re-)introducing arts and humanities into the business curricula enables the integration of reflection and emotions in relation to business and management education. Raelin (2002, p. 66) defines reflection as "the practice of periodically stepping back to ponder the meaning of what has recently transpired to ourselves and to others in our immediate environment." According to Treacy and Gaunt (2021, p. 488) "Reflection concerns thinking about practice before (reflection-for-action), during (-in-action) and after (-on-action) it takes place."

Poetry evokes reflections and emotions and this is what is lacking in business studies (Humphries-Kil, 2017). The receptiveness of business administration students to an art-based method of teaching sustainability is analyzed in this paper. As the topic is quite novel, there is little scientific evidence to it. Existing research in the field has mostly engaged in exploring perspectives of using visual arts (Shrivastava et al., 2012; Ivanaj et al., 2014; Molderez and Ceulemans, 2018), music (Kagan and Kirchberg, 2016), photography (Lin and Li, 2017) collaborative art practice (Illeris, 2012; Ivanaj et al., 2014; Lineberry and Wiek, 2016) and art-based workshops out in nature, including different forms of art (Reason, 2007; van Boeckel, 2014) to teach sustainability. Moreover, only three of the listed studies (Reason, 2007; Ivanaj et al., 2014; Molderez and Ceulemans, 2018) involved business management respondents. Therefore, the goal pursued by this research is to address this gap in the literature on Education for Sustainable Development (ESD) in management studies, examining the effects of using poetry as an art form and how this can stimulate a sustainability mindset for future managers.

A rereading of Benjamin's (1955a) Illuminations from the perspective of sustainability studies was a source of inspiration, in particular "Theses on the Philosophy of History" (pp. 245255), "The Storyteller" (pp. 83-107) and "Unpacking My Library" (pp. 61-69). The paper assumes that Benjamin's ideas relate to a slow journey involving "awakening," "wisdom" and "in a process;" three elements that are at the core of promoting a sustainability mindset. Illuminations is a collection of ten essays first published in German. Benjamin's essays started to become very influential since the nineteen fifties and still are (Smith, 2001; White, 2017). Benjamin (1955b) inspires because "he makes everything no longer familiar" (Leon Wieseltier in the preface, viii and ix). He questions valuing history from the perspective of progress and has reflective thoughts on the concept of loss. $\mathrm{He}$ also argued for being sensible for what happened in the past. 
Links with sustainability are therefore not uncommon. In his work, he elaborates on wondering by wandering and this is the perfect combination for a slow journey, i.e., one of awakening, wisdom and process. These three concepts are linked: awakening is only possible when there is a certain kind of wisdom which can only be acquired in a process-like way.

The paper is structured as follows. The next section will provide a literature review on five items: the influences of Walter Benjamin; a sustainability mindset; sustainable management education; the role of art and art-based teaching methods to foster sustainability; and poetry as an alternative pedagogy for sustainability. This section will be followed by the research method, i.e., analyzing reflective assignments about using poetry in a course on Corporate Social Responsibility. The subsequent sections will provide study results, a discussion and conclusion on the contribution of poetry used in business management education to promote a sustainability mindset.

\section{LITERATURE REVIEW}

\section{Influences of Walter Benjamin}

In the 1980s Walter Benjamin was only known in an inner circle of specialists and academics but a decade later, and since then on, Walter Benjamin has become a well-known reference to the wider audience (Greenberg, 2008). His ideas in the Arcades Project on urban consumer culture inspired scholars (e.g., Akkerman, 2019) to critically reflect upon consumer culture (e.g., Kurylo, 2020), European colonialism in the nineteenth century (e.g., Vandertop, 2016) and refugees (e.g., Alfaro, 2020). Walter Benjamin was born on July 15, 1892 in Berlin, but circumstances forced him to take his life on September 26, 1940 at Portbou, a border town in Cataluny, Spain. This is not just a geographical description, but also a symbolic signifier. Portbou is a place with great historical significance because it was the site of the last battle in the Spanish civil war. Walter Benjamin wrote plenty about borders in a metaphorical way. The monument and site to commemorate Walter Benjamin was inaugurated in 1994 (Greenberg, 2008). But it symbolizes likewise the importance of limits as horizons, embracings, openings, frontiers; all of these concepts are important in relation to sustainability. Walter Benjamin did not specifically write about sustainability. At that time there was not yet the urgency of tackling wicked problems as in the contemporary climate crisis, although Benjamin and his European generation faced wicked problems of poverty, refugees, discrimination in the first catastrophic decades of the twentieth century. Nevertheless, Walter Benjamin was very critical about the urban consumer culture, analyzed in his Arcades Project. He critiqued the bourgeois, and in this process, reflected on fashion, boredom, advertising and progress. He suggested a different way of consuming, one that is more in line with voluntary simplicity (Walther and Sandlin, 2013), consumption in the margin, the un-consumer (Huneke, 2005), the Simple Life (Wagner, 1901). His contribution is neither related to action, nor to activism, but rather to no-action. There are many ways of acting and un-acting is part of the slow journey. Moreover, the circumstances Walter Benjamin was facing, are also symbolic in terms of educating resilient minds that will face many long journeys and blocked borders, before a more sustainable life style is reached.

Three essays from Benjamin's (1955a) Illuminations are used to illustrate three elements of a slow journey. The first one, "awakening," relates to "Theses on the Philosophy of History;" the second one, "wisdom," builds on "The Storyteller;" and the third one, "in a process," to "Unpacking My Library." These three concepts are vital for a sustainability mindset: "awakening" is only possible when there is a certain kind of "wisdom" which can only be acquired "in a process" way.

Walter Benjamin's (1955a, p. 245) “Theses on the Philosophy of History" relates to how to deal with the past and thus with loss. Benjamin (1955a, p. 255) is critical when history is only about "establishing a causal connection between various moments in history." Everything is important because "nothing that has ever happened should be regarded as lost for history" (Benjamin, 1955a, p. 246). With respect to sustainability, Benjamin's (1955a) reflections help to understand the loss of biodiversity and the role of mankind, increasingly seen as a wicked problem that cannot be neglected (IPBES, 2019), from a different angle. In the paper "Environmental Anamnesis: Walter Benjamin and the Ethics of Extinction" Smith (2001) is elaborating on this link. Smith (2001, p. 359) draws on Walter Benjamin to object to an instrumental interpretation of the loss of species, i.e., perceiving them mainly as a "moralistic message." He argues against the way environmentalists use the story of extinctions, i.e., as a symbol of "human moral failings." Lost species are then appraised for their instrumental value because they are used to criticize the role of man in the extinction of species. Smith (2001, p. 363) opposes to the "empathic model" since "this model requires that we place ourselves, insofar as possible, in their shoes, distancing ourselves from the anachronistic influences of our present situation and disavowing the knowledge afforded us by hindsight. Only by divorcing ourselves from our present concerns and developing a feeling for the past can we faithfully represent things as they really were.... As Benjamin remarks, the historian cannot simply blot out everything they know about the later course of history." For Smith (2001, p. 363) it is, however, not only not possible, but also inappropriate to try to "forget who we are." In the latter case we would "lose ourselves entirely in the historical Other and, at the same time, erase history's constitutive role in producing our self-identity." Smith (2001) uses the passenger pigeon as a case to explain a different relationship than using it as a moral tale. The eradication of this species is a notable example of anthropogenic extinction. Instead of using the passenger pigeon as a moral tale of past malpractice, Smith (2001, p. 362) argues for a different ethical relation, i.e., respecting "their difference from ourselves, to refuse to make them subject to our desires, compliant with our expectations, or forced to speak with our words. ... our desire is not to consume or confine them but to conserve the uniqueness of their being." Recognizing the other just because it is, makes "mourning for them" possible. Referring to Walter Benjamin (1955a), the Other is everything and everyone, human or non-human. Missing likeness can only add to a wonder of its otherness. Smith (2001, p. 368) sees mourning as a "reconciliation with the past and its loss. ... it keeps memory alive through the interplay of desire and wonder." 
Con-serving instead of preserving the past, is how Benjamin sees an authentic historical relation. The past must speak for itself. Humans have the power and possibility and thus responsibility "to redeem the subjects of past lives who would otherwise be forgotten" (Smith, 2001, p. 373). Vigilance becomes important to avoid that the past would "disappear irretrievably" (Smith, 2001, p. 374). For Walter Benjamin, "every presentation in history must begin with awakening; in fact, it should deal with nothing else" (Smith, 2001, p. 375, quoting Benjamin).

A focus on mourning and melancholy is also Mark's (2016) advice. Mark (2016) was inspired by Joe Hill, a labor activist, songwriter and member of the "Industrial Workers of the World" an international labor organization that was founded in Chicago. Hill was born in Sweden, but immigrated to the United States of America. He was convicted of murder and executed in 1915. He was innocent, but being an immigrant and an activist made him vulnerable to being condemned. In his essay on "Environmental Loss and Musicking" Mark inverted Joe Hill's saying "don't mourn, organize" by "don't organize, mourn." Although immediate action is required, he feared that "lost environmental attachments, lost species, lost skills, lost forests, lost futures, and lost ways of life" (p. 53) are replaced by-perhaps_-green consuming "as a panacea for pain" (p. 52). His argument is: “... that as a society, if we do not confront our environmental losses together and deal with them, if we do not mourn them properly, we will never slow the melancholic consumption and the production of new product-losses and greater alienation" (Mark, 2016, p. 56). Consumption leads to the repressing of social and environmental loss. Consumers disrupt themselves from their environment and this act of alienation could be seen as an unconscious coping strategy for all the loss. To prevent this, Mark suggests relying on music. Music can give hope, strength, renewal, but Mark (2016) points to another possibility. He borrows the term musicking from Christopher Small (1998, p. 9), emphasizing music as a process and not as a noun; a process in which everybody can take part: the performer, the listener, the dancer, the one who is selling the tickets, the cleaners, because they are all contributing to the process of making music. For Mark (2016, p. 57) musicking is also a verb and it "responds to adversity, melancholy and mourning through fostering social bonds." However, it is not just mourning, it includes the resistance to accept further loss. By emphasizing mourning, Mark (2016, p. 70) does not underestimate the importance of action. On the contrary, the problems with respect to the environment are too urgent to not act, but this must go together with "recognizing, validating and mourning" to avoid that the vicious circle of consuming more to avoid the pain of loss and that other problems will be created. It is precisely the non-action of mourning that gives space to learning about nature and our vulnerabilities.

What musicking is to Mark (2016), is storytelling to Walter Benjamin (1955a). In his essay "The Storyteller" Benjamin (1955a, p. 83) focusses on the loss of storytelling and thereby the loss of wisdom. His storyteller is not the traveler who comes from far away and has something to tell while everybody listens. He is referring to "the resident master craftsman and the traveling journeymen" who are working together in the same rooms (Benjamin, 1955a, p. 84). They shared local tales and traditions "to pass the time and to make their work more interesting and productive. Thus, Storytelling took place in a collective context" (White, 2017, p. 2). It was not a passive act. The way the listener listened, made retelling possible. Every listener was a "potential storyteller who hands down his own version of the story to others. Through storytelling the collective experience of people was passed from one generation to the next (White, 2017, p. 3). Storytelling took place in a collective context. However, what is most important, their words applied to many situations (Benjamin, 1955a, p. 107) because "the storyteller is a man who has counsel for his readers" (Benjamin, 1955a, p. 86). This counsel is wisdom, something that can be reflected upon. A true story is "open-ended, so it provokes reflection and inspires recollection" (White, 2017, p. 3). There is no need to try to explain or to justify. The wisdom is not ready made, there to absorb. It is not a kind of recipe, but "the ability to apprehend and to integrate the lessons of storytelling and life itself" (White, 2017, p. 4). White (2017, p. 4) refers to Kisa Gotami, a well-known story in Buddhism. There is no need to explain the content; the content speaks for itself, but it requires an ability "to apprehend and integrate the lessons of storytelling" and this "requires a state of relaxation," a state of wandering and wondering and this is a slow process. This is not easy because contemporary individuals are mainly trained to reproduce information but barely to interpret or reflect upon it (Raelin, 2002). This was exactly the point Benjamin (1955a) wanted to make: the absence of integrating experience at a deeper level (White, 2017, p. 10).

Musicking and storytelling are not by accident verbs, just like "Unpacking My Library" is not. The emphasis is on the verb to stress the importance of process which takes time. Walter Benjamin's (1955a) analysis in "Unpacking My Library" illustrates this "slow journey" perfectly. When he writes "What I am really concerned with is giving you some insight into the relationship of a book collector to his possessions, into collecting rather than a collection" (Benjamin, 1955a, p. 61), it becomes clear that for a collector the process is more important than the end result. Collecting keeps the collector busy and his entire attention goes to this process. It is a long process and also a never ending one. The process is what gives energy despite the time it takes. And this also counts for a sustainability mindset. A sustainability mindset is not possessed, but activated along the process of "doing."

\section{Sustainability Mindset}

As a concept, a sustainability mindset is not commonly used. Kassel et al. (2016) are among the first to describe it as a theoretical framework. Duchi et al. (2020) analyzed the influence of mindsets on environmental action. Their research is valuable because many people are concerned about sustainability challenges, but few are actively involved in doing something about it. The results of their study show that a growth mindset might be the answer to effectively take action with respect to sustainability challenges. Dweck and Yeager (2019, p. 481) define a growth mindset as "the belief that human capacities are not fixed but can be developed over time." Dweck and Yeager (2019) refer to Giovanni Pico della Mirandola, a key 
thinker of The Renaissance, who was convinced that the very fact that humans are able to transform themselves is what makes them humans. This was a provocative assertion at that time and was "in contrast to historical notions of fixed endowments and predetermined positions in the hierarchy of merit." (Dweck and Yeager, 2019, p. 482). Following Mirandola, Yeager and Dweck (2012) recommend focusing more on the process to be able to work on a mindset that is helpful to address challenges resiliently. Although they are not referring to sustainability challenges in particular, their messages are also interesting in contexts of sustainability. Effort, strategies, focus and persistence characterize the process and these are more important in making a meaningful change than stressing the outcome.

A mindset has a variety of similar terms such as a mental inclination, tendency, habit, a particular way of thinking, a person's attitude or set of opinions to do something, paradigms, worldviews (Kassel et al., 2016). Werhane (2008) and Werhane et al. (2013) use the term mindset interchangeable with mental model, admitting that the term is not always clearly defined. Kassel et al. (2016, p. 3) define it as "the lens through which individuals view the world and their role/place in it, including the underlying assumptions, beliefs and values that inform that lens." This corresponds with how Werhane (2008, p. 463) describes it as " ... mental representations, cognitive frames, or mental pictures of their experiences, representations that model the stimuli or data with which they are interacting, and these are frameworks that set up parameters through which experience or a certain set of experiences, is organized or filtered." Gladwin et al. (1995, p. 880) refer to Norton (1991) to define worldviews as "the constellations of beliefs, values and concepts that give shape and meaning to the world a person experiences and acts within." They make the distinction between two opposing worldviews, technocentrism and ecocentrism, and suggest a new one, sustaincentrism. The criterium to select a worldview should be how the characteristics of a particular worldview fit with what is needed for a sustainable transformation. According to Gladwin et al. (1995, p. 889) a third worldview, i.e., sustaincentrism, is needed because the two other worldviews "do not offer a basis upon which sustainable development can be achieved." This worldview is still "embryonic" (Gladwin et al., 1995, p. 890). One question remains in their point of view: "How do we wish to live?." This also fits with Arne Naess (1973) deep ecology which is about asking deep questions. Instead of focussing on problem solving, one should be reflective and ask questions whether the way we are living now really is the way we want to live (Molderez and Ceulemans, 2018). Relying on problem solving corresponds with the optimistic faith in technology of the technocentrist worldview. The ecocentrist worldview, on the other hand, is very pessimistic about technologies' capacity. Because the damage to nature is irreversible, one should be precautionary.

Kassel et al. (2016) specify when a shift in the mindset can take place. Especially when individuals or societies are faced with an anomaly, a crisis develops and undermines the foundations of the worldview which evolves into a shift in the mindset (Kassel et al., 2016). Anomaly is a theoretical construct, because the question remains how big the anomaly should be before people think differently and act accordingly. Within the context of sustainability, the concepts of competencies, skills, capabilities, abilities, mindsets, and related terms are often defined and described in the same way, and built on comparable constructs (Lambrechts, 2019, 2021). According to Kassel et al. (2016, p. 8) a sustainability mindset is "a way of thinking and being that results from a broad understanding of the ecosystems manifestations as well as an introspective focus on one's personal values and higher self and finds its expression in actions for the greater good of the whole." From this definition three elements are intertwined: knowledge, values and competency. Respectively, these elements can also be seen as a synonym for head, heart and hand (Benjamin, 1955a), which are also often mentioned in relation with sustainability (Shrivastava, 2010). Gretzel et al. (2014) implicitly refer to head, heart and hand when listing six core literacies that characterize a sustainability mindset, i.e., technical, analytical, ecological, multi-cultural, policy and political, and ethical literacy. Kassel et al. (2016) distinguish four main content areas: systems perspective, ecological worldview, emotional intelligence and spiritual intelligence. These areas are distinguished with a business audience in mind. Shortterm thinking, both-and logic, biospheric orientation and reflection, elements of the main content areas of Kassel's (2016) sustainability mindset, are illustrative components of head, heart and hand that are lacking in business education. Rimanoczy (2014) concluded from her research that business education has led to a fragmented understanding of society. The values of business leaders are in complete opposite to what is important in terms of sustainability (Painter et al., 2019). Short-term objectives prevail and the dominating assumption is always either/or. A sustainability mindset is then difficult to align with business leaders because they have never learned to focus on paradoxical thinking, long-term thinking, or interconnectedness. Negative externalities, a well-known concept within microeconomics, illustrates how disconnections are mainstream within economic thinking. Not every economist agrees on the precise link between externalities and sustainability (Van den Bergh, 2010). Negative externalities commonly affect public resources where it is difficult to hold parties accountable such as in a case of environmental pollution, so producers, and even consumers, may blindly generate a negative externality without worrying about lawsuits or fines. Air and water pollution are well-known examples of negative production externalities. Economists often use the existence of negative externalities as an argument for the role of the government, i.e., a well-organized economy cannot exist without the government. Another argument in favor of the government is also that "some positive level of externalities is consistent with sustainability" (Van den Bergh, 2010 , p. 2048). Whatever the idea one has about the importance of the government, the problem is that one is not capable of including third parties, like the environment, in the organization process. Kassel et al. (2016, p. 6) underline this by stating that "The primacy of the value of organizational success has usually been accompanied by a disregard for consequences and impacts on other stakeholders which are seen as limiting return on investment." In the first place, the answer should not be calling for an external control, more government, but a different way of organizing, changing the either/or logic into a 
both/and logic. This is not so simple because especially within Western culture one is used to thinking in binary opposition such as nature/culture, inside/outside, order/disorder, old/young (Cooper, 1990). Dualisms are perceived as a dichotomy, a division into two separate parts and this division creates a dilemma because the splitting up leads to a forced choice between two mutually excluding options only. However, a dualism does not have to be about one or the other, not an either/or, but a both/and combination (Molderez, 2007).

Another difficulty toward prompting a sustainability mindset is "the biospheric orientation." Kassel et al. (2016) contrast it with a solely utilitarian viewpoint. It relates with appreciating and rethinking value. The biospheric orientation closely corresponds with the values that are important with the spiritual intelligence content area. Seeing ourselves as part of nature contradicts with how nature is often seen within an instrumental ethical framework toward nature, i.e., as a source for satisfying human needs (Linzey and Linzey, 2018). Although Linzey and Linzey (2018) focus on animals, their argument for "animal ethics" can be extended to nature in general. Nature is "valuable in themselves and of themselves" (Linzey and Linzey, 2018). Nature as the other is dear to us and not because of any particular instrumental value or because we have something to win. Dear also means appreciated and treasured, fostering long-term involvement.

Reflection is a last element of the sustainability mindset (Kassel et al., 2016) and part of transformative practices (Colomer et al., 2020). Rimanoczy (2014) has found that "leaders and students that reflect on their larger purpose develop more profound levels of engagement toward sustainable actions than those motivated by the desire to create a competitive advantage." This calls for more attention to reflection in programs of management education.

\section{Sustainable Management Education}

It is generally argued that prevailing approaches to teaching business and economics in universities have not changed over the past decades (Wall and Jarvis, 2015). Mintzberg (2004) was already arguing in the beginning of the twenty-first century that MBA programs have been considered to merely produce financial analysts with lack of leadership qualities. Dey and Steyaert (2007) believe that the job of a manager is separated from life in general, despite the equal relevance of soft skills and hard skills for managers (Pixley, 2004).

Traditional methods of teaching managers are entirely based on declarative knowledge and employ strictly cognitive techniques (Chia and Holt, 2008; Taylor and Ladkin, 2009). In the circumstances of the sustainability crisis, business faculties recognize the necessity to include a sustainability course in their curriculum (Shephard, 2008; Raivio, 2011). However, the program of such courses, usually called "Corporate Social Responsibility," still employs conventional educational methods. For sustainability, many authors argue that for such an allencompassing and complex topic, a cognitive approach is insufficient (Warburton, 2003; Reason, 2007; Shephard, 2008; Schneider et al., 2010; Shrivastava, 2010; Shrivastava et al., 2012; Longo et al., 2017) as knowledge does not automatically lead to action and sustainable behavior is motivated by much more than declarative information (Frisk and Larson, 2011). Management education is still mainly built on twentieth century paradigms of unrestricted growth and consumption. Re-thinking the entire management education framework is a prerequisite for responsible leadership: instead of being "best in the world" management education has to be transformed toward "best for the world" (Globally Responsible Leadership Initiative, 2012, p. 1). The results of Remington's (2013) assessment showed that business majors did not improve any of the key sustainability competencies after having an introductory course on sustainable development. Therefore, Wall and Jarvis (2015) argue that "training" managers is not enough, there is a need for educational transformation. Such transformation is essential as it can be a trigger for launching self-organizing processes toward sustainability. Universities, due to their multistakeholder collaborations, play a very important role in sustainable development (Manring, 2014). Business education needs a more holistic approach (Bradbury, 2003; Shrivastava, 2010). Thus, innovative approaches in education are required to adequately address sustainability challenges (Jänicke, 2008; Burns, 2011; Boons and Lüdeke-Freund, 2013; Lineberry and Wiek, 2016; Wall, 2016a,b; Wall et al., 2019b).

Students in business and management study programs have been subject to a number of studies s (e.g., Ng and Burke, 2010; Nejati and Nejati, 2013; Bahaee et al., 2014). Perhaps following the observation that economic study programs have been mainly focusing on profit maximization, business and management students themselves have been portrayed as being the "selfserving" type adhering to egoistic values (Lopez et al., 2005; Ng and Burke, 2010), yet even within this group of students, a variety of viewpoints and perspectives has been described, with groups of students adhering to pro-environmental and sustainable values (Ng and Burke, 2010; Lambrechts et al., 2018b). The most crucial achievement of education for sustainable development and factor for transforming society toward sustainability is a change in behavior (Marcus et al., 2010; Frisk and Larson, 2011), which Reason (2007, p. 40) calls "Learning III, transcendence of the ego world and an experience of deep participation in the processes of the planet." Within universities the need for such a change is recognized, however, they experience difficulties in promoting behavioral transformation, and the introduction of stand-alone courses are mainly examples of normative approaches and not transformative ones (Lambrechts et al., 2018a). As Svanström et al. (2008) explain, besides obtaining knowledge, such a change requires developing values (motivation) and skills. Passion is argued to be the key, since science is not enough (Shrivastava et al., 2012). Passion is practical (Shrivastava, 2010); provides a holistic approach, involving body, mind and emotions; facilitates creativity (Baron, 2008); transforms and motivates (Shrivastava et al., 2012), and that motivational effect is lasting (Toms and Toms, 1999). The value of passion is also important in a business context (Smilor, 1997; Shrivastava, 2010). Passion leads to commitment (Bierly et al., 2000), which is an indispensable prerequisite of managing sustainably (Shrivastava, 2010). Hence, for a transformative approach toward sustainability, emotional engagement (Shrivastava, 2010; Ivanaj et al., 2014), deep 
experience (Naess, 1990) and passion (Shrivastava, 2010) are required. Emotions and passion are also considered to be components of strategic or radical change (Sanchez-Burks and Huy, 2009) and the essence of any behavioral change (Mossholder et al., 2000; Smollan, 2006). Passion nurtures creativity and according to d'Orville (2019, p. 68) "Creativity is at the heart of sustainability." Creative activity can recover the sense of belonging to the natural world (Bateson, 1972) and is essential for designing the relationship between humans and nature (Ehrenfeld, 2009). Moreover, creativity brings inspiration and empowerment (d'Orville, 2019) and plays a crucial role in ESD (Sipos et al., 2008; Sandri, 2013). Taking into consideration the above-mentioned, art as an embodiment of creativity is considered next as a special innovative approach to ESD for business management students.

\section{The Role of Art and Art-Based Teaching Methods to Foster Sustainability}

Art has been an indispensable part of human existence for many centuries. Therefore, it has developed a unique characteristic to generate emotions (Eisner, 2002, 2008; Shrivastava et al., 2012), which can help create passionate connections between humans and nature, and contribute to fostering harmonious, balanced life (Taylor and Ladkin, 2009; Shrivastava et al., 2012; van Boeckel, 2014). Viewed from the perspective of behavioral change, art offers a new vision of the world (Goodman, 1976), it provides depths when reflecting on complex ideas, shifts mindsets (Shrivastava et al., 2012) and has a reorganizing power (Bateson, 1972). Furthermore, essential for ESD as well, art promotes good conscience (Bateson, 1972) and sustainable values (Reid et al., 2006; Shephard, 2008; Sauerwein et al., 2017); provides a deep understanding of sustainability issues (Shrivastava et al., 2012) and brings awareness to them (Shephard, 2008; Lin and Li, 2017; Sauerwein et al., 2017). Art can be responsible for triggering and facilitating action, which is essential for sustainability (Reid et al., 2006; Reason, 2007; Shephard, 2008; Sauerwein et al., 2017) and, in general, impacts sustainable development (Shrivastava et al., 2012).

In the past decades, art-based techniques for sustainable education started to appear in scientific research and within academic circles. Nussbaum (2010) stressed the importance of arts and humanities in education to provide broader learning processes focusing on imagination, creativity, and critical thinking. Such an approach would also be beneficial for businesses and industries: "Leading business educators have long understood that a developed capacity to imagine is a keystone of a healthy business culture" (Nussbaum, 2010, p. 112). These are essential to develop what she calls "central capabilities": life, bodily health, bodily integrity, senses, imagination and thought, emotions, practical reason, affiliation, play, control over one's environment (Nussbaum, 2010, 2011). Specifically, within the context of future-oriented sustainability education, the central capabilities have been connected to the individual sustainability competencies (Lambrechts, 2021). Also, UNESCO encourages to employ art methods to teach sustainable development in its "Road Map for Arts Education" (UNESCO, 2006) and "The
Seoul Agenda: Goals for the Development of Arts Education” (UNESCO, 2010).

In management education, art is rare (Ryman et al., 2009; Taylor and Ladkin, 2009). Although little research exists on the topic, art making and art contemplation have been recognized to produce benefits such as to promote a sense of interconnectedness in self (Taylor and Ladkin, 2009) and community (Ivanaj et al., 2014); understanding of underlying concepts (Ivanaj et al., 2014; Molderez and Ceulemans, 2018), and encouraging to take action (Ivanaj et al., 2014). Moreover, art-based methods have been discovered to foster a holistic approach (Ivanaj et al., 2014; Molderez and Ceulemans, 2018), critical thinking (Molderez and Ceulemans, 2018) and leadership (Ivanaj et al., 2014). More so, using art to promote ESD for students of management and business faculties is uncommon. Molderez and Ceulemans (2018) explore the contribution of contemplating paintings to understanding concepts related to sustainability and developing skills which are necessary for addressing complicated sustainability issues. Ivanaj et al. (2014) organized a workshop of "aesthetic practice pedagogy" asking students to illustrate a sustainable added value of their business activity via a painting of their own creation. Attempts have been made to explore various art forms such as expressive writing, visual art, drama, applied theater (Wall et al., 2019a). Poetry, in particular, has considerable potential as an innovative approach to teach sustainability, but it is rather unusual in business education.

\section{Poetry as an Alternative Pedagogy for Sustainability}

Poetry has been recognized to have an impact on people in terms of two key sustainability dimensions: societal and environmental. In the field of ESD, the effects of poetry have been studied from both perspectives. From the environmental point of view, poetry has mostly been used as a part of interdisciplinary workshops. For example, van Boeckel's (2014) students practiced writing their own poetry out in nature and then sharing it with each other. This exercise provided students with opportunities to develop creativity and the feeling of interconnectedness with each other and the natural world. Another example is using poetry within the "Sustainability Transdisciplinary Education Model" (Clark and Button, 2011), a contemporary approach linking art, science and community. These experiences take place at galleries, museums and exhibitions, and the teaching modes include poetry, among other art forms. Although it is impossible to discuss the contribution of poetry independently, the whole approach claims to promote deeper understanding of sustainability, elicit critical thinking and even spur the desire to make a change. Walshe (2017) studied the effect of using poetry to develop students' perceptions of the nature of sustainable development during their geography lesson. The analysis of students' in-depth interviews demonstrated that poetry contributed to promoting more critical and affective engagement with issues of sustainability and a more holistic appreciation of it. Moreover, more responsible social behavior was observed. Walshe (2017) emphasized students' primary focus 
on the environmental dimension of sustainability. Walshe (2013) also used poetry in a workshop organized for geography trainees (future teachers), where they listened, read and created poems, both in class and outside, taking inspiration from the local environment. Some of the poems written by the participants revolved around environmental topics, others took a more holistic approach to sustainable development. The feedback included the discovery of poetry's "power" and its relevance for ESD. Those trainees used poetry at their own geography lessons afterwards. Some scholars have used an approach of ecocriticism to explore the contribution of poetry to ESD. Ecocritical literature comprises of texts illustrating environmental challenges of modern society. Garrard (2007) used ecocritical poetry in multiple field trips with his students, as well as in various literature courses to increase the awareness of environmental issues. Similar approaches were accomplished by Matthewman (2010) who used poetry to promote students' understandings of sustainability. A poem chosen for her study displayed the complexity of social and environmental sustainability aspects and was observed to have the potential to develop a more holistic understanding of sustainability in students (Matthewman, 2010). In general, ecopoetry has been shown to foster reflections on the corresponding topic and broaden the comprehension of environmental issues. Moreover, it can potentially alter traditional conceptions of nature and has a power to make students reconsider the world. As Finch-Race and Weber (2015, p. 162) explain, "ecopoetic approach foregrounds the capacity of poetry to embody the destabilizing effects of environmental changes on human consciousness."

Poetry used in ESD has also its merits from the societal perspective. Mazza (2016) argues that both reading and writing poetry provides profound therapeutic benefits. Also, as part of literature, poetry can encourage development of emotional intelligence (McMullen, 2003) and help create a bond between people (Bugeja, 1994). Poetry lay at the core of "Poetry for People" study (Rangel, 2016), a setting for self-discovery and creativity which allowed for self-development opportunities. Its participants composed, shared and discussed poems. The program was aimed at encouraging a holistic view via a "therapeutic tool for healing and mind body spirit development" drawing on poetry (Rangel, 2016, p. 547). Poetry can also be effectively used to teach empathy and explore social problems (Furman, 2005). Finally, poetry also works as part of reflection exercises in ESD. Reflection contributes to preparing students for the challenging problems of sustainability in modern society, developing systemic thinking and creative approach (Eaton et al., 2017). Poetry has also been discussed to encourage reflection in the process of fostering leadership, providing an opportunity for expanding self-awareness (Burns et al., 2015).

In the area of education, through poetry researchers have reported benefits such as: emotional exploration and competency (Foster and Freeman, 2008), empathy (Collett and McLachlan, 2006; Foster and Freeman, 2008; Wolters and Wijnen-Meijer, 2012), broadening perspectives (Millan, 1996; Foster and Freeman, 2008), self-discovery and development of imagination (Collett and McLachlan, 2006; Foster and Freeman, 2008; Brown, 2015). Moreover, poetry has been recognized to enrich professional communications (Collett and McLachlan, 2006; Foster and Freeman, 2008; Brown, 2015) and foster better connections among people (Foster and Freeman, 2008). A contribution of poetry to developing consciousness-raising (Collett and McLachlan, 2006; Ciardiello, 2010) and promoting reflection (Collett and McLachlan, 2006; Foster and Freeman, 2008; Wolters and Wijnen-Meijer, 2012) has also been recorded.

In business, poetry has been beneficial with respect to improving organizational performance (Windle, 1994; Morgan, 2010), contributing to understanding of management within companies (Kostera, 1997) and promoting creativity and innovation (Grisham, 2006; Borgerson, 2008; Morgan, 2010). For managers in particular, poetry is argued to help developing skills applicable to business (Morgan, 2010), promoting critical thinking and emotional intelligence (Morris et al., 2005; Fraiberg, 2010) and inspiring action (Grisham, 2006). Writing poetry in ESD for business management students is rare, Reason explorations (2007) being an exception.

Poems are a way of expressing emotions, feelings, ideas. As Faulkner (2020, p. 4) states, writing poetry is often used "to make sense of difficult life experiences." Poems can be used to be reflective about the future, the role in society, the economic system of profit maximization, of our vulnerability, our lack of possibilities. One way of seeing poetry draws on Faulkner (2020, p. 11) who describes poetry as "showing, not telling, our (in)humanity and all of its mysteries." She refers to Leggo (2008) while adding other dimensions: "Poetry creates or makes the world in words. ... Poetry invites us to listen. Poetry is a site for dwelling, for holding up, for stopping, ... Poetry invites ways of uniting the heart, mind, imagination, body and spirit." Poetry is used by qualitative researchers because of "its slipperiness and ambiguity, its precision and distinctiveness, its joyfulness and playfulness" (Faulkner, 2020, p. 12). Within poetic inquiry, it can be seen as "a form of qualitative research in social sciences that incorporates poetry in some way as a component of investigation (Faulkner, 2020, p. 13, quoting Prendergast, 2009). Her own definition reads as follows: "Poetic inquiry is the use of poetry crafted from research endeavors, either before a project analysis, and/or poetry that is part of or that constitutes an entire research project. The key feature of poetic inquiry is the use of poetry as/in/for inquiry" (Faulkner, 2020, p. 14). Poetry can be used to present research data, as representation (Faulkner, 2020). Thus, representation is not neutral, but used to make a statement, like Reale (2015) who uses poetic inquiry as a form of activism to try to influence policy changes and create awareness with respect to refugees. In this context, poems have an instrumental value, but their intrinsic value is of equally importance, i.e., a value of wonder, of becoming open for what is different.

Using poetry for reflection is a way of meeting Walter Benjamin's (1955a, p. 83) call for storytelling in "The Storyteller." Poetry is similar to the stories Walter Benjamin is alluding to. Poems stimulate to be an active recipient. Although it is not always easy, it stimulates reflection. Writing your own poetry and then reading it aloud in front of an audience, creates a different and even more authentic way of communication than just talking about the reflections you have. The heart, hand and body come together, or "that old co-ordination of the soul, the eye and the 
hand ... that of the artisan which we encounter wherever the art of storytelling is at home" (Benjamin, 1955a, p. 107). It evokes the collective context in the workplace Benjamin was writing about. Especially in Corona times, when students are sitting behind their screens, poetry offers a possibility to share what they feel.

\section{METHOD}

\section{General Approach}

A qualitative research approach was chosen for this research because the aim of the study was to analyze students' perceptions and impressions after being exposed to poetry with respect to promoting a sustainability mindset. The respondents were invited to participate in a reflection assignment after the particular lecture on Ethics, Values and Art in the Corporate Social Responsibility class. The lecture was supposed to prepare students for the tasks and to attempt to set them in an appropriate state of mind for answering the open-ended questions that were part of the reflection assignment.

The respondents not only had to read the selected poems and share their feelings about them, but also had to carry out their own search for poems, as well as practice writing poetry by themselves, amongst answering open-ended questions. This research was carried out by students following three different courses at KU Leuven University, Faculty of Economics and Business, Campus Brussels, Belgium in the academic years 20192020 and 2020-2021. The first group followed the elective course Corporate Social Responsibility of the 3rd Bachelor year of the program "Bachelor of Business Administration" in the academic year 2019-2020. From a total of 37 students who opted for this course, 20 handed in the reflection assignment. The second group joined the Summer School Sustainable Management, organized by KU Leuven and Odisee, in September 2020. Although all the 20 students had time to answer the questions during the specific lecture, only 12 uploaded their files. The third group of 7 students opted for the elective course Service Learning and Social Entrepreneurship and 5 sent their responses in April 2021. The students were free to reply either in Dutch or in English, but the majority responded in English (57\%). Table 1 gives an overview of the participants. In total 37 students, or $58 \%$, participated in a written reflection assignment. For the purposes of anonymizing the students, each respondent was assigned a number.

The study took the form of a reflection assignment for two reasons. Firstly, a written reflection assignment is more likely to provide an opportunity to express independent and controversial opinions as participants feel safer and have less concerns about potential reactions to their replies. Independent thinking is vital when the concern is to stimulate deep learning (Warburton, 2003; Hermes and Rimanoczy, 2018). Moreover, offering students challenges to thinking, can have a positive impact on student engagement (Emblen-Perry, 2018). Reflection assignments are frequently used for learning and research purposes in (higher) education settings. The approach adopted in our study follows that of reflective writing as explained by Kalman (2020), who also refers to the concept of expressive writing (Britton et al., 1975). Kalman (2020) places reflective writing in the context of the hermeneutic process (inspired by Heidegger, 1962; Gadamer, 1976), which enables students to understand textual extracts. Previous research has shown that leaning improves when students write about their thinking (Fellows, 1994). Within the context of individual sustainability competencies, hermeneutic approaches have been proposed by Lambrechts and Van Petegem (2016). Specifically within the context of poetry, in which students are asked to reflect on and write poems about sustainability, the hermeneutic approach is a valuable process. Furthermore, other forms of writing assignments, as described in the literature, provide additional methodological background for our study. For example, Dunlap (2005, 2006) suggests “journaling” and refers to Gillis (2001, p. 49) to define the concept as "a method of promoting exploration and facilitating reflection on learning and new experiences within the context in which the learning unfolds" (cited in Dunlap, 2005 , p. 72). Such reflective assignments-whether in the form of journaling (over an extended period) or as a single assignment within a course-are believed to strengthen understanding and critical thinking (Dunlap, 2005). Furthermore, as Dunlap (2005, p. 72) argues, "it is also a powerful research tool for capturing students' reflective practice, conceptual change, thinking, and learning. (...) because journal writing serves valid instructional and research purposes, the data collection may intrude less into students' authentic learning experiences." Moreover, and this is specifically within the interest of our study, reflective writing assignments have the potential to foster transformative learning experiences (Wilson et al., 2008). Such transformative learning experiences aim for a lasting impression, become part of the learners' own narrative, and lead to behavioral impact (Wilson et al., 2006). Transformative learning is an important topic in the debate on sustainability in higher education and individual sustainability competencies as well (Sterling, 2011; Lambrechts et al., 2018a; Förster et al., 2019).

Secondly, due to the circumstances, in-person interviews would have been very hard, if not impossible, to organize because of the COVID-19 pandemic. In order to obtain more substantial and informative data, only open-ended questions were used. However, this shortcoming turned out to be an opportunity because writing is more comfortable than talking with respect to reflection. To prevent the spread of infection, not only domestic social distancing restrictions had been introduced everywhere in the world, global trade and travel had been compromised as well. It resulted in a drastic change of the world life's paradigm. Multiple consequences were observed, negative for economics and society, but positive for the environment. More importantly for the present study, people naturally started to pay more attention to sustainability issues. That created an appropriate base to use the perspective of COVID-19 crisis in examining the potential influence of poetry on forming a more sustainable way of thinking and a sustainability mindset.

\section{Data Analysis}

Three types of data analysis were used, utilizing "data analysis triangulation" (Leech and Onwuegbuzie, 2007, p. 557). The primary data was analyzed combining "word count," "manifest content analysis," and "latent content analysis" (Leech and Onwuegbuzie, 2008). 
TABLE 1 | Participants in the reflection assignment "Sustainability and Poetry" (2020 and 2021).

\begin{tabular}{|c|c|c|c|c|}
\hline Program & $\begin{array}{l}\text { Total number of students who } \\
\text { followed the lecture on values and art }\end{array}$ & $\begin{array}{l}\text { Total number of students who } \\
\text { participated in the reflection } \\
\text { assignment ( } \% \text { of total) }\end{array}$ & Period & $\begin{array}{l}\text { Assigned } \\
\text { numbers }\end{array}$ \\
\hline $\begin{array}{l}\text { Bachelor of Business } \\
\text { Administration-Course Corporate Social } \\
\text { Responsibility }\end{array}$ & 37 & $20(54 \%)$ & May 2020 & $1-20$ \\
\hline $\begin{array}{l}\text { Summer school Sustainable } \\
\text { Management-Workshop on Values and } \\
\text { Sustainability }\end{array}$ & 20 & $12(60 \%)$ & $\begin{array}{l}\text { September } \\
2020\end{array}$ & 21-32 \\
\hline $\begin{array}{l}\text { Bachelor of Business } \\
\text { Administration-Course Service Learning } \\
\text { and Social Entrepreneurship }\end{array}$ & 7 & $5(71 \%)$ & April 2021 & 33-37 \\
\hline Total number of students & 64 & 37 (58\%) & & \\
\hline
\end{tabular}

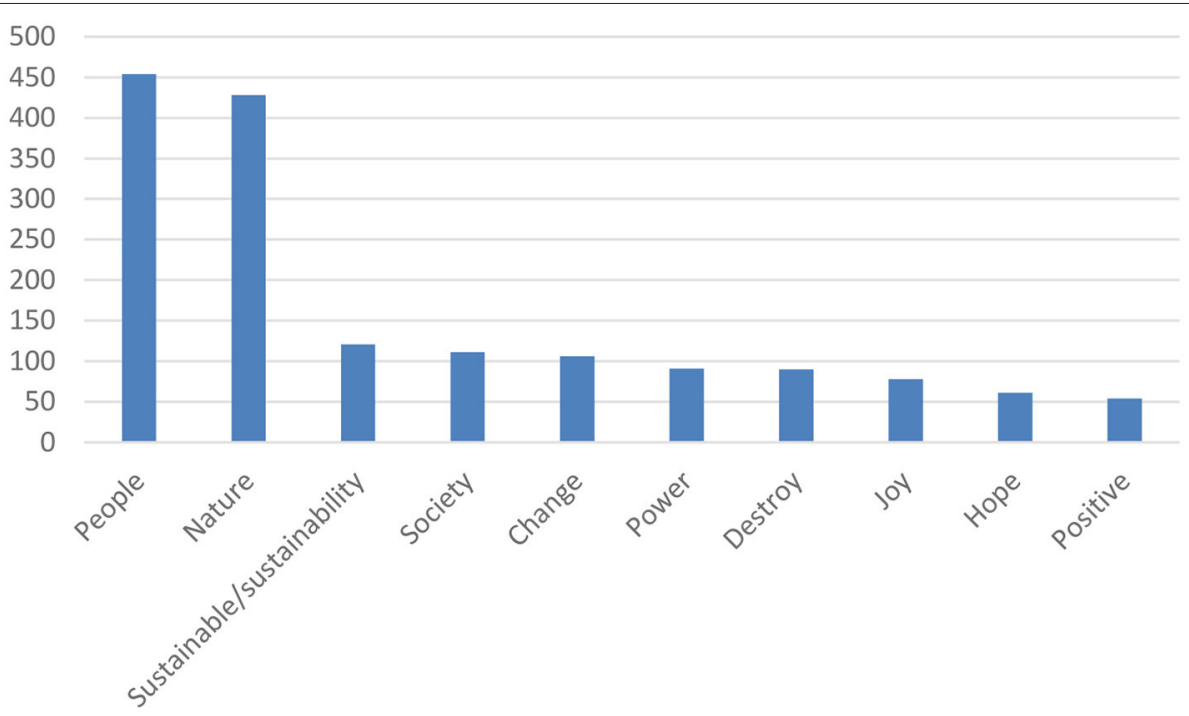

FIGURE 1 | Word count of the 10 most used words in the reflection assignments.

"Word count" was used, because this data analysis tool is helpful in identifying patterns (Leech and Onwuegbuzie, 2011, referring to Miles and Huberman, 1994). However, there are also weaknesses when applying this tool (Morgan, 1993). Decontextualizing the word can make the word no longer understandable (Leech and Onwuegbuzie, 2007) and using a word less frequently does not necessarily entail that the word is not an important concept (Braun and Clarke, 2006; Leech and Onwuegbuzie, 2007). The computer-assisted qualitative data analysis software "Atlas.ti" was used for the word frequency query. Although there are many features within "Atlas.ti" for qualitative analysis (Scales, 2012; Paulus and Lester, 2016), only the word count option was applied. A "linguistic fingerprint" of each respondent was not made (Leech and Onwuegbuzie, 2008, referring to Pennebaker et al., 2003), because the words were not separately counted for each reflection assignment. However, the purpose of the word count. was to get a global picture of the most common used words.
"Atlas.ti" counted in total 45,638 words for the 37 reflection assignments or on average 1,200 words per respondent. Figure 1 shows the ten, most used words. Although words with rather negative connotation also appeared in the answers, like destroy (90), ruin (37), pollution (20), suffering (7), words with a positive idiom were the most common, like joy (78), hope (61), positive (54).

An "open coding process" (Berg, 2009) was employed for both the manifest and the content analysis. In order to increase reliability of the analysis, two techniques were applied. First, the code list was used to reduce a possibility of unintendedly changing the code's meaning during the analysis (Richards and Morse, 2012). The list was generated inductively, which is considered less reliable (Catanzaro, 1988), but was chosen to offer an opportunity to identify meaningful units with an open mind. Second, in order to further increase reliability of the analysis, the coding process was performed repeatedly, starting from different parts of the text (Downe-Wamboldt, 1992). Table 2 shows the code tree. Interesting features of the written assignment were first 
TABLE 2 | Common descriptions and codes.

\begin{tabular}{|c|c|c|}
\hline & Common description & Code \\
\hline \multirow{7}{*}{$\begin{array}{l}\text { Interconnectedness } \\
\text { between nature }\end{array}$} & Deep connection & Bond \\
\hline & Alienated from nature & Alienation \\
\hline & $\begin{array}{l}\text { Hope and despair; grief and } \\
\text { pain }\end{array}$ & Emotions \\
\hline & $\begin{array}{l}\text { Taking nature into account } \\
\text { because of its importance in } \\
\text { our lives }\end{array}$ & Care \\
\hline & $\begin{array}{l}\text { We owe our existence to } \\
\text { nature; we depend on } \\
\text { nature; abuse of nature }\end{array}$ & Human/nature relationship \\
\hline & $\begin{array}{l}\text { The earth has some kind of } \\
\text { ceiling that we can't exceed; } \\
\text { globalization }\end{array}$ & Planetary boundaries \\
\hline & $\begin{array}{l}\text { Nature is like man; } \\
\text { civilization as water in } \\
\text { summer }\end{array}$ & Metaphor for human \\
\hline \multirow[t]{3}{*}{$\begin{array}{l}\text { Overwhelming } \\
\text { power of nature }\end{array}$} & $\begin{array}{l}\text { Lovely and destructive; } \\
\text { source of energy and } \\
\text { destruction }\end{array}$ & Duality of nature \\
\hline & $\begin{array}{l}\text { Very beautiful and therefore } \\
\text { indescribable power; nature } \\
\text { decides; always wins }\end{array}$ & Power of nature \\
\hline & $\begin{array}{l}\text { Nature is in harmony; man } \\
\text { depends on nature; we are } \\
\text { irrelevant }\end{array}$ & Nature vs. man \\
\hline
\end{tabular}

listed in an excel file and then codes were independently noted by two researchers. The coding process was structural and thematic (Wolff et al., 2019).

\section{Structure of the Reflection Assignment}

The reflection assignment was divided into four parts containing different tasks. The first part was designed to "set a scene" for students and served the purpose of promoting reflection on the concepts of the study's topics. Respondents were supposed to read two poems and to answer questions about their impressions. The second part related to the selection of a poem to make people think about the sustainability challenges in the course of the current COVID-19 crisis. In the third part the students were asked to create their own poem, followed by the fourth part to reflect upon the role of poetry with respect to societal challenges.

With respect to the first part, the selected poems dated back to the nineteenth and twentieth centuries, before all the current sustainability issues became prominent. It was done deliberately, so that the poems could genuinely be perceived as a piece of art, not as an informative message. The first of the selected poems, "I am like a leaf" by Yone Noguchi, a poet of Japanese origin. Yone Noguchi wrote in English as well, featuring a subtle, delicate style, never projecting his own vision in his works, calling "so persistently to the reader to exercise his imagination" (Davis, 1913, p. 5). This corresponds to the idea of the study of allowing the respondents to form their own impression and not imposing any procured concepts. It also ties in with Benjamin's (1955a, p. 83) idea of storytelling in "The Storyteller": the poem speaks for itself and does not need any further explanation. Taking into consideration the rich history of Japanese poetry and Noguchi's background of living in the United States, Great Britain and Japan, Noguchi genuinely appreciated nature through his poetry, filling it with metaphors and often expressing the interconnectedness of humanity and the environment. “... ( $\mathrm{He})$ seemed, indeed, to have the freedom of two worlds, and to find reality in one as often as in the other" (Ransome, 1910, p. 528). The topic of the poem is concentrated on the human-withinthe-environment concept, which might contribute to developing the feeling of interconnectedness, an important element for a sustainability mindset (Kassel et al., 2016).

\author{
I Am Like A Leaf \\ Yone Noguchi (1875-1947). \\ The silence is broken: into the nature \\ My soul sails out, \\ Carrying the song of life on his brow, \\ To meet the flowers and birds. \\ When my heart returns in the solitude, \\ She is very sad, \\ Looking back on the dead passions \\ Lying on Love's ruin. \\ I am like a leaf \\ Hanging over hope and despair, \\ Which trembles and joins \\ The world's imagination and ghost.
}

The second selected poem, "Water," is written by Ralph Waldo Emerson, an American author and philosopher, "intellectual" (Hanlon, 2016) and "poet-scholar" (Cavanaugh, 2002). Emerson was leading the transcendentalist movement, believing in the superiority of nature and its high potential to teach humanity. As Cavanaugh (2002, p. 25) explains, Emerson's poetry “suggests that a harmonious relationship with nature... may be achieved by all people who are willing to hear ... message in nature" and his poetry "communicates... so that others seek truth in nature" (Cavanaugh, 2002, p. 27). In Emerson's essay "Nature," "Man studies the relationships of all objects in order to comprehend the unity of nature" (Cavanaugh, 2002, p. 28). This perspective directly relates to taking action and acting responsibly, one of the most essential skills for obtaining a more sustainability mindset (Sterling and Thomas, 2006; Barth et al., 2007; Rieckmann, 2012; Gretzel et al., 2014; Kassel et al., 2016), which is scarcely being addressed in business and management study programs (Lambrechts et al., 2013).

Water

Ralph Waldo Emerson (1803-1882).
The water understands
Civilization well;
It wets my foot, but prettily,
It chills my life, but wittily,
It is not disconcerted,
It is not broken-hearted:
Well used, it decketh joy,
Adorneth, doubleth joy: 
Ill used, it will destroy,

In perfect time and measure

With a face of golden pleasure

Elegantly destroy

After reading these poems students were asked to reflect upon three questions. The first question focused on the concept of interconnection: "In what perspective did the poems make you think about the interconnectedness between nature and humanity?." The aim to understand whether poetry could help people to see themselves within the environment and promote the sense of interconnectedness for the purposes of deeper learning is in line with Naess (1973) concept of "deep ecology" and Bateson's (1972) idea that creativity fosters the sense of belonging to the natural world. Interconnectedness presented particular interest for the research question because, on the one hand, "the arts are a vehicle for making passionate connection to nature" (Shrivastava et al., 2012, p. 32) which, on the other hand, might lead to forming a sustainability mindset (Kassel et al., 2016). This idea was suggested by Reason (2007), although not stating any definite conclusions. He reported that students felt interconnectedness with nature during his artbased workshop and "cautiously claimed" that they would start acting more sustainably afterwards (Reason, 2007, p. 40). Taking into consideration the above-mentioned points, it was decided to include this second question, "What ideas do you think the poems express about the overwhelming power of nature?." The purpose was to encourage a reflection on the topic of ecocentrism (Gladwin et al., 1995; Washington et al., 2017). The third question, "What thoughts of yours did the poems prompt in terms of reassessing values (cf. Schwartz et al., 2012) of the society in the course of the current COVID-19 crisis?," aimed at understanding whether the poems prompted students to think about the reassessment of basic human values happening amidst the pandemic and whether this situation was shifting the collective mindset toward a more sustainable one. In order to introduce some criteria useful for evaluating possible changes in society, the respondents were asked to apply Schwartz's (1992) Theory of Basic Human Values, which was discussed during the class just before participation in the research. Schwartz (1992) identified universal cross-cultural values which are recognized by citizens all over the world. Within his framework, two core dimensions are distinguished: self-transcendence vs. selfenhancement and openness to change vs. conservatism. This model presented particular interest for the present research because self-transcendence values are specifically relevant to responsible behavior in terms of sustainability. To reduce redundancy in answers the students were not asked to refer to the 19 values that Schwartz et al. (2012) later suggested as a way to refine the theory of basic individual values.

In the second part of the reflection assignment, students were asked to search for an appropriate poem by themselves and to explain why they considered this poem to be an illustrative case to make people think about economic, environmental and societal aspects of sustainability challenges in the course of the current COVID-19 crisis. This exercise was proposed to inspire further reflection on the topic of potential power of poetry to promote sustainability-wise thoughts. As for the research, it was essential to see what kind of poems the respondents would consider suitable.

The third part contained allegedly the most challenging task: "Please create your own poem which would, from your point of view, provide a better understanding of what has to change in the way modern society is organized."

The fourth part most explicitly expressed the goal of the present research. It aimed at understanding students' perceptions regarding relevance and potential benefits of poetry being used in the management education with the purpose of changing toward a sustainability mindset. Four questions had to be answered: (1) How do you think poetry can help people to reflect upon societal challenges?; (2) In which ways can poetry make people think differently about economy?; (3) What kind of positive aspects of the current COVID-19 crisis in terms of evolution of sustainability mindsets can you think about?; (4) How could poetry be used in triggering a transition toward a sustainability mindset?

Throughout the whole assignment, and especially its fourth part, reflection on the discussed topics was intentionally encouraged. The tasks were designed in this way because the practice of reflection can provide new insights (Burns et al., 2015) and is proved to contribute to deep learning (Boud et al., 1985; Rogers, 2001; Warburton, 2003; Wilson et al., 2008; Hermes and Rimanoczy, 2018), which, in its turn, can promote more sustainable behavior (Schneider et al., 2010; Kassel et al., 2016).

\section{RESULTS}

\section{Interconnectedness, Overwhelming Power of Nature and Values}

After reading the poems "I Am Like A Leaf" by Yone Noguchi and "Water" by Ralph Waldo Emerson the students replied to three questions related to (1) the interconnectedness between nature and humanity; (2) the overwhelming power of nature; (3) the reassessing of values in the course of the COVID-19 crisis.

The majority of the respondents addressed the concept of the bond between nature and humanity in the perspective of humanity's need for nature, the harm that humanity has brought to the environment and the necessity to take care of the planet (see Table 2). Judging by these answers it can be seen that the students took this topic to heart and immediately started reflecting on the modern sustainability issues when simply asked about the bond. Some students explained the poems in a literal way, i.e., how flowers are symbol for happiness and abundance; and dead leaves for sadness (Respondent 20). They saw nature as a metaphor for humans, i.e., leaves for expressing hope and despair (Respondent 11). Most of the time the two poems were a trigger for a deeper reflection about the alienation from nature and the destructive effect of this (Respondent 18), feelings of integration, tranquility and anxiousness (Respondent 5). Some students mentioned the interconnectedness itself:

"I feel a deep connection between humanity and nature, which are inextricably linked with deep roots that reach further than we can easily imagine." (Respondent 18) 
When addressing the second question, although some of the students still had the interconnectedness between humans and nature from the first question in mind, most of them agreed on the overwhelming power of nature, describing it almost poetically:

"Everything humanity knows they inherited or took over of nature, nature holds quasi all the knowledge." (Respondent 9)

Especially the dual side of nature was mentioned, i.e., nature being beautiful and destructive and how small humans are compared to nature. The power of nature was described in its capacity to turning against man when it is disturbed. According Figure 1, negative consequences for humanity if not acting sustainably, i.e., "destroy" in the word count, were mentioned 90 times. The importance of the correct behavior, i.e., "change" in the word count, was also emphasized in more than 100 times. Respondents wrote about the necessity of change in that perspective. COVID-19 crisis was again mentioned and referred to as a form of punishment. Students pointed out humanity's unappreciation of nature. As it could be seen from the answers, the question is likely to have achieved its purpose, making students contemplate the ecocentric concept. One student even mentioned the reflection by himself:

"We can also reflect our own feelings and thoughts with the nature, which can be interesting to look for some new views on certain topics and for new ways of thinking." (Respondent 17)

As it was discovered, the poems made the respondents reflect upon different values-"security," "self-enhancement," "hedonism" and, most prevalently, "universalism." Answering this question, students sounded almost unanimously, describing the society coming closer together and acting responsibly for the sake of everyone else:

"We don't need much to live.... We should invest and develop local resources" (Respondent 29).

Many respondents wrote about society reassessing values in this difficult time of COVID-19 crisis toward universalism and benevolence or a more societal focus. Although a minority was skeptic about the reassessment of values, e.g., "Now that we are starting up, profit is the focal point and not sustainability" (Respondent 22), but students also saw the urge of the situation "If we don't change, we will face dark times" (Respondent 11). Thoughts also went in the direction of values that are affected in a negative way, especially security and stimulation:

\footnotetext{
"Our society will no longer be the same and we will have to change our safety norms. And because we are locked in so often, I am losing a bit the joy of life" (Respondent 35).
}

One student explicitly pointed out the potential role of poetry in such contemplations:

"I see this period as an opportunity for reflection for both my own personality and the universal vision of our society. To me, such poems and other forms of expression seem to be a suitable means of reflection." (Respondent 3 )

And some students took the opportunity to play around with the words, creating an answer that comes close to a poem:

\begin{abstract}
"Nature is a kind of witty. Humanity is foolish. Technology and maximization give us the false impression that we can exercise some kind of control. Yet nature is around the corner, lurking, waiting. Ready to remind us that nothing can replace it. It's both gorgeous and dangerous.... The water understands us, sees (seas?) (ceases?) us. It's soft and playful. But with a face of golden pleasure, it will remind us of its power." (Respondent 30)
\end{abstract}

\section{Selection of Poems}

In the second part of the assignment, students were asked to provide an example of a poem which, in their opinion, makes people think about economic, environmental and societal aspects of sustainability challenges in the course of the COVID-19 crisis. Table 3 gives an overview of the selected poems. The number that corresponds with the respondent who chose it, is put between brackets. Many students interpreted the question literally and looked for a poem about COVID-19. Yet, most of the students cited poems on an abstract topic, some even chose poems written in the eighteenth century, like May to April from Philip Frenau. Respondent 10 chose this poem because the COVID-19 crisis was very severe in April and May 2020 at the time when this workshop took place. A few students found ecocritical pieces, literally describing the environmental damage caused by humans; nature poetry, like the ones by Robert Frost; and poems that tackled sustainability issues. The majority of the poems were related to nature while societal challenges like poverty were rare. One poem focused on the problem of unemployment and some were critical about the economic system that prioritizes wealth creation, like "Economic Storm Clouds" written by Bob Gotti in 2008, the year of the financial crisis. A few students also opted for poems that had no direct link with nature, sustainability or COVID-19, like "Recuerdo" by Edna St Vincent Millay was chosen by Respondent 3:

"It is a reflection of my own feelings within this crisis 'We were very tired, we were very merry': on the one hand we are very tired, on the other hand the crisis offers an opportunity to see happiness in small things." (Respondent 3)

The selection of the poems often showed how students think about the COVID-19 pandemic. Jabberwocky by Lewis Carroll was selected by Respondent 21 because of the senselessness that is characterizing life:

\footnotetext{
"We don't really make sense and have been doing senseless things and expect senselessly. We keep continuing like we know where we are going, which we don't." (Respondent 21)
}

Students gave various explanations for their choice. Respondents mostly referred literally to certain verses in the poems; an example of this is Respondent 22 explaining the choice for 
TABLE 3 | Selected poems by business students.

\begin{tabular}{|c|c|c|c|c|}
\hline Covid-19 poems & Ecocritical poems & Nature poetry & Sustainability poems & $\begin{array}{l}\text { No direct link with nature, } \\
\text { sustainability, COVID-19 } \\
\text { or different from a poem }\end{array}$ \\
\hline $\begin{array}{l}\text { 1. Harvest, Ann } \\
\text { Scarborough Moore, } 2020 \\
\text { (18) }\end{array}$ & $\begin{array}{l}\text { 1. The Question, Theo } \\
\text { Dorgan, n.d. (20) }\end{array}$ & $\begin{array}{l}\text { 1. May to April, Philip } \\
\text { Frenau, } 1787 \text { (10) }\end{array}$ & $\begin{array}{l}\text { 1. The Mission, Debbie } \\
\text { Singh, n.d. (5) }\end{array}$ & $\begin{array}{l}\text { 1. Naakt (Naked), Hetty } \\
\text { Combs, } 2016 \text { (14) }\end{array}$ \\
\hline $\begin{array}{l}\text { 2. De Wereld (The World), } \\
\text { Martin Gijzemijter, } 2020 \text { (19) }\end{array}$ & $\begin{array}{l}\text { 2. Warned, Sylvia Stults, } \\
2015 \text { (1) }\end{array}$ & $\begin{array}{l}\text { 2. Fire and lce, Robert } \\
\text { Frost, } 1920 \text { (9) }\end{array}$ & $\begin{array}{l}\text { 2. The Planet Doctor, Julie } \\
\text { Anna Douglas, n.d. (7) }\end{array}$ & $\begin{array}{l}\text { 2. Recuerdo, Edna St. } \\
\text { Vincent Millay, } 1920 \text { (3) }\end{array}$ \\
\hline $\begin{array}{l}\text { 3. The Great Realisation, } \\
\text { Tomos Roberts, } 2020 \text { (4) }\end{array}$ & & $\begin{array}{l}\text { 3. A minor bird, Robert } \\
\text { Frost, } 1928 \text { (6) }\end{array}$ & $\begin{array}{l}\text { 3. Economic Storm Clouds, } \\
\text { Bob Gotti, } 2008 \text { (12) }\end{array}$ & $\begin{array}{l}\text { 3. Jabberwocky, Lewis } \\
\text { Carroll, } 1871 \text { (21) }\end{array}$ \\
\hline $\begin{array}{l}\text { 4. Coronagedicht } \\
\text { (Coronapoem), Klaske } \\
\text { Bosma, } 2020 \text { (2) }\end{array}$ & & $\begin{array}{l}\text { 4. Tapistry, Lesley Elaine } \\
\text { Greenwood, } 2013 \text { (11) }\end{array}$ & $\begin{array}{l}\text { 4. De smaak van het leven } \\
\text { (Taste of life), Wil Melker, } \\
2017 \text { (15) }\end{array}$ & $\begin{array}{l}\text { 4. Laat ons een bloem } \\
\text { (Leave them a flower), Louis } \\
\text { Neefs, } 1970 \text { (26) }\end{array}$ \\
\hline $\begin{array}{l}\text { 5. Coronavirus A poem, } \\
\text { Martin Kaduc, } 2020 \text { (13) }\end{array}$ & & $\begin{array}{l}\text { 5. Trees, Joyce Kilmer, } 1913 \\
\text { (22) }\end{array}$ & $\begin{array}{l}\text { 5. Health is wealth, Raja } \\
\text { Basu, } 2007 \text { (16) }\end{array}$ & $\begin{array}{l}\text { 5. What they did yesterday } \\
\text { afternoon, Warshan Shire, } \\
2015 \text { (28) }\end{array}$ \\
\hline $\begin{array}{l}\text { 6. Poem: covid-19, } \\
\text { Mohammed Salihu, } 2020 \\
\text { (17) }\end{array}$ & & & $\begin{array}{l}\text { 6. How long till it's gone, } \\
\text { Maxine Raggatt, } 2020 \text { (27) }\end{array}$ & $\begin{array}{l}\text { 6. You say that you love rain, } \\
\text { William Shakespeare (32) }\end{array}$ \\
\hline $\begin{array}{l}\text { 7. The Walls, Maria Meziani, } \\
2020 \text { (25) }\end{array}$ & & & $\begin{array}{l}\text { 7. Dear Earth, Nicola } \\
\text { Jackson, } 2016 \text { (29) }\end{array}$ & $\begin{array}{l}\text { 7. Kindness, Naomi Shihab } \\
\text { Nye, } 1952 \text { (33) }\end{array}$ \\
\hline $\begin{array}{l}\text { 8. What if instead of being } \\
\text { behind these kids are } \\
\text { ahead, Jaime Ragsdale, } \\
2020 \text { (31) }\end{array}$ & & & $\begin{array}{l}\text { 8. Mother Earth, Sophia E. } \\
\text { Valdez, 2019. (36) }\end{array}$ & \\
\hline $\begin{array}{l}\text { 9. In the time of the plague, } \\
\text { N. Scott Momaday, } 2020 \\
\text { (34) }\end{array}$ & & & $\begin{array}{l}\text { 9. I'm here: poem about } \\
\text { unemployment, R. JO, } 2021 \\
\text { (37) }\end{array}$ & \\
\hline
\end{tabular}

“Trees" written by Joyce Kilmer in 1913: "A tree is too important to exhaust."

The poems also encouraged them to think about reassessing values related to sustainability, environmental issues and the need for a change, like in "Kindness" by Naomi Shihab Nye:

"It is about that you have to lose something before you really appreciate something" (Respondent 33)

The poems were often chosen because of the feelings of hope, like in "The Great Realisation" by Tomos Roberts (Respondent 4), but also because of the guilt, sadness and loss they evoked, like in "The Walls" by Maria Meziani:

"This is a good expression of how it feels I think. I constantly think about the good things we now have to stop and I miss it." (Respondent 25)

Students also referred to the poems' emotional influence when the selection was theirs. Respondent 18 explained his choice for "Harvest" by Ann Scarborough Moore as follows:

"It makes you think as well as the example poems, but here there is still more room for emotion. I find this very interesting, of course, the emotional story strongly affects you." (Respondent 18).

Some pointed out that the poems reminded them of people bonding and willing to help each other more during the pandemic. Respondent 19, selecting "De Wereld" (The World) by Martin Gijzemijter is an illustration of this:

\section{"We are uncertain about the future, but together we will get through} it." (Respondent 19)

\section{Creation of Poems}

All the respondents wrote their own poems although such a reflection assignment was very uncommon for the curriculum of business studies. A few respondents remained figurative in their endeavor, attempting to create an abstract piece of art. In some of those examples, though it was not explicitly mentioned, sustainability issues could be clearly identified. The created poems may be sorted in to the following categories: describing the pandemic; environmental issues; reassessing values; musing about what could be and a need for taking action. There are common elements in the poems, particularly in complying with conventional poetic patterns, but the topics chosen and images constructed vary, demonstrating the students' insight and potential of the activity. Three poems are cited below. The names of the students are added to appreciate their creation. Their poems were selected because the students volunteered to read their poem in the class. The poems were written in English, so they did not need to be translated.

We continue marching forward On an earth round and round 
In the depths of our sorrows, the heights of our pride

Our ancient problems are always to be found

Differentiated by a new coat, to make lively the old If we really want change we'l have to change ourselves It doesn't take appreciation for the warmth

But persistence to make it through cold

The heat in our legs, from our endlessly going on

Fades swiftly as we stand still to think about what we've done Worn out cartilage, our future bleak

Yet we don't care, as right now we have everything we need

Arno Stulens, 2020

Oh lord, oh lord please be aware

We still want nature to live and share

If we go further with the mindset we have

In 30 years we won't laugh

Our actions can do more than you think

Nowadays we still live on a cloud that is pink

Consume less, don't use plastic and think about your waste

I warn you, nature and our behavior will get a whole other taste

Maud Bloemen,2020

The feeling of needing

I was alone, needing a real hug,

Hugging a teddy bear

Deep down in the night

Missing my home

Thinking about the ones,

That feels like home

I was alone, needing a light

Which feels like the sun

Like a lovely day on the sea

Like a memory of a sunset

Like my loved ones

Lighting up my life

I was lost, needed to be found

By myself, with the help of hope,

The hope that I had and lost

Into the shadows of my fears,

Like a forgotten song

That I can't recall

I was lost, needed someone,

Someone to talk to

Between the people who listened,

Wondered who understood

Everybody heard me

A few people understood.

Burcu Özdemir, 2021
The students took the task seriously and tried to create traditional poems in the sense that they show an effort to rhyme. The first poem by Arno Stulens reflects on changing the mindset and how difficult that is. The second poem by Maud Bloemen is precise and concise; with rhyming duets. It starts lamenting and ends straight forward saying what we should do and in this ways addressing behavioral change. The third poem by Burcu Özdemir is structured into sextets and a looser rhyme. This poem is melancholic and conveys the idea of a person isolated, away from their home-town and loved ones because of the pandemic. Though it is very personal, the ending lines could also apply to the global crisis:" everyone heard, few understood."

\section{Impact of Poetry}

The reflection assignment ended with four questions related to the impact of poetry.

When first asking about how poetry can help to reflect upon societal challenges (poverty, environmental, etc.), most students mentioned the ways poetry can illustrate the essence of the problem and encourage reflection due to different possible interpretations:

\footnotetext{
"Poetry is a subtle way to point out these problems" (Respondent 14) "A poem is a form of expression that each individual can interpret differently. First and foremost, it helps to reflect on a personal level about current problems..." (Respondent 3)

"A poem has the power 'to hit' people with reality that a scientific paper simply hasn't" (Respondent 9)

"Poems allow people to think in a different way. It provides a deeper reflection of life." (Respondent 5)

"Poetry can give another perspective on these challenges because a poem is not black or white" (Respondent 27)

"Poetry helps to become more tolerant for other worldviews" (Respondent 33)
}

A few students paid attention to the emotional constituent of poetry:

"I believe that through books, you can most effectively transmit
emotions between a creator of art and the reader/viewer. To me
it is the most effective art type and poetry is the pinnacle of this."
(Respondent 8)
"Because poems often make you think more deeply, you can imagine
how the social challenges actually take place. By reading poems you
also immediately get the emotional and warm feeling about certain
circumstances, so that you can quickly put yourself in the place of
people who have to live in that specific situation." (Respondent 10)

The link between poetry and behavioral change was also made:

\footnotetext{
"Through poetry one can tell the story in a different way, a story that sticks with people. A person can gain insight and change his behavior through a poem. A well-written poem suggests emotions." (Respondent 12)

"To be able to change the behavior of people, you have to touch their feelings. Poetry is then the best choice." (Respondent 36)
} 
However, a few students did not believe that poems could have a beneficial contribution to the discussed matters or doubted that enough people could be triggered by poetry:

\begin{abstract}
"I personally do not believe that poetry can have a major impact on society. There have been countless numbers, reports, campaigns and even strikes that should make it clear to people that change is needed." (Respondent 1)

"A lot of people don't seem to care about poetry. We should target it where it is needed most, but I doubt that where it is needed most cares about poetry." (Respondent 21)

"I think it is difficult to reach people with poetry. Poetry takes time to be understood, digested." (Respondent 30)
\end{abstract}

The second question aimed at the role of poetry to think differently about the economy. Almost all respondents discussed the properties of poetry to promote deeper understanding, feeling of involvement and profound connection with economic issues because of either the special artistic language or imagery. Some students also appreciated poetry because of the opportunity to talk about economics in a "less serious way" (Respondent 27). In students' opinion, poetry led to reflection, which could prompt taking actions and making changes:

\begin{abstract}
"Poetry can play an important role because it can focus attention on societal challenges and when we feel involved in this, we will change more quickly... Art makes it possible for both individuals and companies to look at sustainability in a different way, to encourage us to reflect and to act on our feelings." (Respondent 4)

"Poems can make you realize how bad a particular problem can be by making certain metaphors or references. If you compare the economy with death, for example, people will immediately be able to see that the economy is in a bad state and that urgent action must be taken." (Respondent 2)

"It [poetry] is also important to confront people with the failures of the system in a direct and concrete way of communicating if the goal is to rethink the entire system." (Respondent 7)

"Economy is mostly about numbers and money and profit ... but in this way you can show the soft aspects." (Respondent 22)

"Poetry is a subtle way of showing the behind the scene of economic impacts." (Respondent 29)
\end{abstract}

Moreover, students mentioned "holistic view" that poems provided, debates that they inspired, and even critical thinking that they encouraged:

"Poems allow us to think critically about different themes. It also allows people to form their own opinion about current issues. What do you think about the current economy? Isn't there too much waste? How would I approach things differently? Or are we just doing well? It offers the opportunity to reflect and possibly take action yourself. On the other hand, poetry is an ideal outlet for creative souls. That way you can express your opinion. This can be a source of inspiration for someone else. And so the ball starts to roll. It can be seen as an action-reaction system where many new ideas can be created." (Respondent 15)

The third question focused on the relationship between the COVID-19 crisis and changes in mindsets. Students listed many changes that they had noticed in people's way of thinking and behavior. The following changes were mentioned the most: higher appreciation of nature, everything people have and life in general; strengthened relationships; support of local production; local tourism; teleworking; less carbon dioxide; discovering new hobbies. A few times the respondents specified that because of the COVID-19 crisis people had a stunning discovery that acting sustainably was feasible:

\footnotetext{
"We show more compassion and take action to protect each other and ourselves." (Respondent 2)

"...many people went cycling, walking, but others also found new hobbies such as gardening or bird watching. ...I think this period has taught us that we can get more energy from nature, from relationships with friends and family and not from overconsumption." (Respondent 4)

"The quarantine also forced businesses and people to adapt to other lifestyles, ...might open people's eyes that there are other ways of operating a business and providing services that are more environmentally friendly." (Respondent 6)

"People are rediscovering the local producers and the importance of the maintaining of this production and supply. I think people's awareness has changed on themes like sustainability, environment and economy because of the hard confrontation of the limits of today's system." (Respondent 7)

"Man is being taken out of his bubble by the COVID-19 crisis and has time to reflect on his actions in recent years... I think this crisis will lead to a behavioral change..." (Respondent 12)

"I think people will come out of this crisis more self-aware. They will be happier with what they have." (Respondent 13)
}

However, some students were not so convinced about the changes:

"What kind of positive aspects? None to be honest. We always say that this time it will be different, and more often than not, it isn't. I have a pretty pessimistic view on this." (Respondent 21)

The fourth and final question was related to the role of poetry to trigger a transition toward a more sustainable mindset. Most students pointed out the power of poetry to encourage reflection. Some of them stated that such a transition could be triggered with the help of illustrative examples or metaphors in the poems, emotions that they elicit, or even a direct confronting message:

\footnotetext{
"Poems can touch people in a different, deeper way than other channels. To trigger a more enduring mindset, you really have to touch people in a deeply personal way. They have to make the switch of mindset. It has to emotionalize them in such a way that they won't forget." (Respondent 5)

"The art of indirectly addressing a problem with a few words on a blank page is an art in itself. Poetry can help reflect and analyze problems in the future." (Respondent 11)

"The poems should certainly not be too straight forward, this would detract from the transition. People must be made to think for themselves to guarantee a permanent transition." (Respondent 18) "Poetry is accessible because of the peace it exudes. Poetry does not call out, it whispers. This art form can approach people in a quietly accessible way. In addition, its sharpness is also a good stimulus to make people think." (Respondent 33)
} 


\begin{abstract}
"Poetry is an outstanding way to express feelings by its nature. The transitions toward a more sustainable mindset can happen with poems because it would be easier and creative to describe your thoughts." (Respondent 37)
\end{abstract}

From the quotes it becomes clear that poetry allowed the respondents to think in a different way about life, economics, the societal challenges that take place. The respondents got time to think about life and the way they want to live. Poetry gave the possibility of seeing other perspectives, of becoming tolerant for other worldviews. Poetry was hitting many students and this awakening triggered them to act accordingly a sustainability mindset.

\section{DISCUSSION}

The most prominent and essential idea that the data suggests is that due to its emotional constituent, poetry encourages reflection, emotional intelligence and creativity which are important components for a sustainability mindset (Kassel et al., 2016; Humphries-Kil, 2017; Hermes and Rimanoczy, 2018). Especially creating your own poem can be considered as an embodiment of creativity, which is vital for sustainability (d'Orville, 2019) and a way of expressing emotions, ideas and feelings (Eisner, 2002 and 2008; Faulkner, 2020). The analysis of the respondents' perceptions and impressions shows support for the existing knowledge about the emotional power of poetry (Foster and Freeman, 2008; Mazza, 2016), in business context (Grisham, 2006; Fraiberg, 2010), education (Nussbaum, 1998) and sustainability education in particular (Walshe, 2017). Respondents suggested that emotions were motivating people to act as was also found in the analysis by Mossholder et al. (2000) and Smollan (2006). As emotional experience is one of the goals of ESD, it is quite customary for a researcher to aim for it initially. Taylor and Ladkin (2009), for instance, connect art-making by management students with emotional experience, although their research did not involve sustainability concepts. Reason (2007), van Boeckel (2014), Ivanaj et al. (2014) and Molderez and Ceulemans (2018) also emphasize the importance of emotions in their art-based approaches to teaching sustainability. However, none of them studied the effects of poetry, therefore the results of the present study could be considered as a contribution to the existing field. Students emphasized the power of poetry to trigger emotions, especially when own poems can be selected and created. The study has shown that business students are open for this approach. Poetry touches in a deeper way and allows to express their feelings, something that is often forgotten in business studies, but equally important as in arts and humanities. Integrating reflection assignments related to poetry or other forms of art in the curriculum of business programs will balance its rather instrumental structure. By focusing on poetry, this study has provided a different perspective on business and management education. As business schools have been accused of fundamentally unsustainable approaches, focusing on the bottom line, adopting and reframing sustainability in a reductionist approach (e.g., the criticism provided by Elkington, 2018), our study results point toward the importance of arts to foster holistic sustainability mindsets, truly taking into account different dimensions of sustainability. Results also confirm earlier findings that business students are not purely interested in profit, nor are they the self-serving type ( $\mathrm{Ng}$ and Burke, 2010; Lambrechts et al., 2018b). Especially in business studies there is a need for evoking emotions (Humphries-Kil, 2017) and poetry is stimulating this.

In this research, the most commonly mentioned quality of poetry turned out to be promoting reflection, which is confirmed in the studies of Collett and McLachlan (2006), Foster and Freeman (2008), Wolters and Wijnen-Meijer (2012), all in the area of medical education, where poetry is recognized as the most beneficial art-based approach. In the area of ESD, poetry was used with the main purpose to promote reflection (Reason, 2007, Eaton et al., 2017, van Boeckel, 2014 and Walshe, 2017). In our study, when students were asked to create their own poems, all of them accomplished the task. An inference could be made that they found poetry to be an appropriate outlet for their thoughts and ideas which might have accumulated during the reflection stages of the research. This is indirectly confirmed by van Boeckel's (2014) workshop out in nature, where respondents composed poems as well. Based on the results of the present research, poetry has the potential to encourage and develop individual sustainability competencies related to emotional intelligence, critical thinking and reflection, in line with Eaton et al. (2017) and with the existing insights in how reflective writing encourages critical thinking of students (Dunlap, 2005). The reflective assignment helped students criticize the dominant economic system where only profit counts. They expressed the contemporary problems related with being alienated from nature and were reflective about the instrumental view on nature (Smith, 2001; Linzey and Linzey, 2018). The majority of the poems created by the students illustrated an urge for change, but also showed elements of musing, which could be seen as a melancholic version of musicking (Mark, 2016). This corresponds with Faulkner's (2020) point that writing poetry is beneficial when one is facing difficult times. Many students looked back at what is lost (Benjamin, 1955a) and the poems helped to put their feelings into words. In this way, the poems triggered mourning to reconcile with the past and what they had lost (Smith, 2001), not only because of COVID-19, but also because of the challenges of not putting nature first.

This study also suggest that reflection promoted by poetry can lead to taking action, which was quite a popular topic in the responses. Taking action and acting responsibly is one of the key competencies for addressing sustainability challenges (Sterling and Thomas, 2006; Rieckmann, 2012). Effective development of such competencies is likely to be fostered by reflective learning (Colomer et al., 2020) and a component of passion (Shrivastava, 2010). Respondents' opinion about reflection leading to acting responsibly is also valuable because reflection is considered to be a key sustainability competency (Rieckmann, 2012) and acting upon reflection is one of the goals for reorientation learning processes toward sustainable development (Barth et al., 2007). As such, the interlinking between (moral) reflection and acting responsibly might be empirical examples of the individual virtuous competency as conceptualized by Blok et al. (2016), i.e., the process in which students reflect (normative element), which encourages them to act responsibly (action taking). 
The reflection assignments of students also included elements of the transformative potential of poetry within the context of sustainability and critical views regarding lifestyles in light of the COVID-19 pandemic. Reflecting about these issues and writing poems encouraged students to make it their own narrative, potentially also leading to behavioral impact; elements which are critical for transformative learning (Wilson et al., 2006). Judging by the students' replies, an inference could be made about behavioral change. Answering the questions about poetry's potential influence, respondents were making links from poetry through emotions and reflection to the change much needed for transforming the society into a more sustainable one. The results of the present study confirm Grisham's (2006) suggestion that poetry, even used in business context, can spur action and Svanström et al. (2008) idea that behavioral change toward sustainability needs reflection.

In the end, the question can be asked whether poetry promotes developing individual sustainability competencies such as those related to emotional intelligence (Wiek et al., 2011), critical thinking (Rieckmann, 2012), or individual virtuous competence (Blok et al., 2016). Although some students referred to a change in behavior, what really mattered was the possibility of openness, of void, of slowing down the journey they are used too, offering a site for dwelling (Leggo, 2008). Poems are like the stories in Walter Benjamin's (1955a) “The Storyteller." They are openended and provoke reflection (White, 2017). The three concepts of a slow journey came together, i.e., awakening, wisdom and process. Students saw similarities between poems and knowledge and called it another knowledge. Poems encouraged the students to think deeper. It took time to grasp a meaning out of many, but this reflection process led to insight. This is in line with Dweck and Yeager (2019) who argue that human capacities can be developed over time. Students can become familiar with this slow process by reflection assignments related to poetry. This is highly relevant in programs for management education because deeper levels of engagement are developed when more attention for reflection is given (Rimanoczy, 2014). Poetry as an alternative pedagogy is a step toward transforming education (Wall and Jarvis, 2015), an education of heads, hearts and hands, of awakening, wisdom and process.

\section{CONCLUSION}

Education plays a decisive role in the future of society in light of sustainability, as it prepares students for citizenship and ideally enables them to lead meaningful and flourishing lives (Nussbaum, 2010; Lambrechts, 2021). Unfortunately, current teaching methods are not always adequate in achieving the necessary transformation toward sustainability (Frisk and Larson, 2011; Kristjánsson, 2017) and even specifically designed ESD programs do not succeed in fostering behavioral change among students (Frisk and Larson, 2011). Therefore, it can be claimed that innovative approaches to sustainability education must actively be searched. Other findings show that using art in a business course enriches the educational experience and allows students to understand the course material at a deeper level (Ryman et al., 2009). Art-based approaches can be a powerful method in helping people to deal with sustainability aspects alternatively to traditional learning (Ivanaj et al., 2014). Moreover, it contributes to understanding and even implementing such complex concepts as "sustainable strategy" in a business setting (Ivanaj et al., 2014).

The paper described how poetry can be relevant for ESD in management context. Literature proposed some inferences that a positive answer to this question might be expected, and as the results suggest, the expectations were met. In the course of the research, business administration students were provided with a reflection assignment after a lecture about values and art in the Corporate Social Responsibility course. As it appeared, reading poetry, attempting to interpret it, searching for an appropriate poem and creating an own piece can have the potential to make a difference for ESD according to the respondents. Within qualitative studies, strategies for generalizability focus on the possibility of transferring the results of the research (Daniel, 2019). While the respondents were all students at a Faculty of Economics and Business in Belgium, the findings have meaning for other geographical sites too. Through promoting reflection on the topics of sustainability, poetry can contribute to rising interest in sustainability aspects, deeper involvement in them and can even be fostering change in behavior. Hence, developing innovative teaching methods, especially for management majors is essential in the disposition of the current sustainability crisis. Business faculties of some universities have started to implementing novelty techniques. Innovative research can bring valuable experiences and subsequently form the basis of a new educational paradigm which will be well-equipped to provide the next generation of responsible managers addressing sustainability challenges of the upcoming time. Of course, one cannot expect that poetry will be the only answer to the question of how to stimulate pro-sustainable behavior. This would reduce poetry to a tool and therefore fit in the category of belief in easy solutions. This would also go against what a sustainability mindset is about. A holistic approach is needed, one that integrates a both/and logic, i.e., different ways are needed at the same time.

Four limitations to the present research stand out. Firstly, at the time the research was conducted, KU Leuven among other universities switched to an online educational mode due to the ongoing COVID-19 pandemic. Therefore, a potentially productive group discussion after filling out the reflection assignment could not be organized. It would have been beneficial if the students could have shared their own ideas, had a debate on the topic, cited their own poems and reflected upon the emotional impact with their peers. Although face-toface contacts were preferred for group discussions, the online tools were continuously adapting, allowing for separate break out rooms and students were becoming more familiar with online discussions. Doing the same reflection assignments in three different groups allowed for slight changes of the format. The first group only uploaded their reflection assignment, in the second group volunteers were asked to read their own created poem and in the third group a joint online reflection exercise was integrated. In the course of art-based 
workshops, for instance, positive effects of group work were pointed out by Ivanaj et al. (2014). van Boeckel (2014), as an example of multiple perspectives that group work entails, described the courage that it took to participants to read out loud the poems they created. Moreover, there are examples of art-based group work bringing people together (Illeris, 2012; Rangel, 2016), which is directly related to the societal sustainability dimension.

Secondly, the study was conducted among students who opted for an elective course on Corporate Social Responsibility. It indicated their initial interest in the subject and, as a result, might have provided some bias, influencing their opinions. It is quite hard to attempt to speculate on the topic from the perspective of a different disposition, but it might also have happened that people less involved in sustainability issues would have had more memorable impressions. It could have been the result of a combination of two components: a sustainability topic being not very familiar to them and an introduction of poetry which is not regularly used in business management education.

Thirdly, the participants of the present research were mainly of Belgian nationality, being Dutch native speakers. In order to provide them with an opportunity to fully express their points of view with no limitations, the students were allowed to give their answers in Dutch. Their answers were translated into English and subsequently analyzed in English. This could have proposed some bias as it had probably been harder to see clearly what the respondents meant or to read in between the lines.

Fourthly, the research took place during the lockdown due to COVID-19 with an impact on research process and results. The questions were very direct and might have steered the students' answers in a particular direction. Students expanded on interconnectedness, overwhelming power of nature, reassessing values because they were stimulated to do so despite the openness of the questions. This approach was related with the context. The pandemic forced online lessons with limited possibilities to guide the students. As a consequence, the questions had to be very clear. The results also show very positive responses with respect to behavioral change. However, after 1 year, evidence shows that people want to take up their lives again: traveling, having parties, etc. Governments still have to rely on measures to force people to be careful. Making promenades in the local area does not seem to be satisfying all the needs people have. Further research can focus on the sustaining aspect of behavioral change. After all, the effective change of the sustainability mindset of the students on the long term was not analyzed. The reflection assignments provided initial data, which was used to understanding the general response of how poetry was taken in the context of business education. The cross-sectional type did not allow for observing the same respondents' replies to the same questions through time. This data might have proposed new views and perspectives. Nevertheless, the used method, i.e., reflection assignments related to a course, opens new approaches for collecting data.
Taking into consideration the above-mentioned limitations, it is important to suggest potential research directions for the future. Firstly, it would be appropriate to carry out a follow-up study with the same students to see if their perspectives changed over time. It could be discovered whether they started paying more attention to poetry or sustainability issues, or maybe even used those in the course of their work which helped them to be more sustainable managers. Secondly, as understanding of interconnectedness of systems (Svanström et al., 2008; Frisk and Larson, 2011; Wall and Jarvis, 2015) and feeling connected to nature plays an important role for ESD, it would be beneficial to organize a poetry workshop out of the classroom with group discussions included. Thirdly, as the present study was not aimed at measuring any effects, it would be interesting to conduct a long-term experiment during the whole academic year described as follows. Students could be asked to do a different poetic exercise, a small one, at every Corporate Social Responsibility class. For example, they could propose their interpretations to poems and discuss them; search for a poem, most appropriate for the subject of the attended lecture; create their own poems, etc. At the end of the academic year this group could fill out a reflection assignment about the influence of such exercises and the results could be compared with another group having the same major but not participating in poetic exercises. This way the potential effects of poetry and the reflection on sustainability topics that it fosters as well as its contributions to ESD could be seen more explicitly.

\section{DATA AVAILABILITY STATEMENT}

The datasets presented in this article are not readily available. Requests to access the datasets should be directed to ingrid.molderez@kuleuven.be.

\section{ETHICS STATEMENT}

Ethical review and approval was not required for the study on human participants in accordance with the local legislation and institutional requirements. Written informed consent for participation was not required for this study in accordance with the national legislation and the institutional requirements.

\section{AUTHOR CONTRIBUTIONS}

IM and DB: conceptualization, formal analysis, and investigation. IM, DB, and WL: methodology. IM and DB: data curation and original draft preparation. IM, DB, and WL: writing, review, and editing. All authors contributed to the article and approved the submitted version.

\section{ACKNOWLEDGMENTS}

The authors would like to thank Professor Paola Spinozi, Università di Ferrara, and Dr. Andrea Casals Hill, Pontificia Universidad Católica de Chile, for their valuable comments and feedback. 


\section{REFERENCES}

Akkerman, A. (2019). "Philosophical urbanism of Walter Benjamin," in Philosophical Urbanism. Cham: Palgrave Macmillan, 1-42. doi: 10.1007/978-3-030-29085-6_1

Alfaro, G. G. (2020). "Walter Benjamin in Fortress Europe: refugees and the ethics of memory in an (ex)border town," in Public Memory in the Context of Transnational Migration and Displacement, eds S. Marschall (Cham: Palgrave Macmillan Memory Studies), 243-265. doi: 10.1007/978-3-030-41329-3_9

Bahaee, M., Perez-Batres, L. A., Pisani, M. J., Miller, V. V., and Saremi, M. (2014). Sustainable development in Iran: an exploratory study of university students' attitudes and knowledge about sustainable developmenta. Corp. Soc. Responsib. Environ. Manag. 21, 175-187. doi: 10.1002/csr.1312

Baron, R. A. (2008). The role of affect in the entrepreneurial process. Acad. Manag. Rev. 33, 328-340. doi: 10.5465/amr.2008.31193166

Barth, M., Godemann, J., Rieckmann, M., and Stoltenberg, U. (2007). Developing key competencies for sustainable development in higher education. Int. J. Sustain. Higher Educ. 8, 416-430. doi: 10.1108/14676370710823582

Bateson, G. (1972). Steps to an Ecology of Mind. New York: Ballantine.

Benjamin, W. (1955a). Illuminations. Edited and with an introduction by Hannah Arendt. Translated by Harry Zorn. London: The Bodley Head.

Benjamin, W. (1955b). Illuminations. Edited and with an introduction by Hannah Arendt. Translated by Harry Zorn. Preface by Leon Wieseltier. New York, NY: Schocken Books.

Berg, B. L. (2009). Qualitative Research Methods for the Social Sciences. Boston: Allyn and Bacon.

Bierly, P. E., Kessler, E. H., and Christensen, E. W. (2000). Organizational learning, knowledge and wisdom. J. Organ. Change Manag. 13, 595-618. doi: 10.1108/09534810010378605

Blok, V., Gremmen, B., and Wesselink, R. (2016). Dealing with the wicked problem of sustainability: the role of individual virtuous competence. Bus. Prof. Ethics J. 34, 297-327. doi: 10.5840/bpej201621737

Boons, F., and Lüdeke-Freund, F. (2013). Business models for sustainable innovation: state-of-the-art and steps towards a research agenda. J. Clean. Prod. 45, 9-19. doi: 10.1016/j.jclepro.2012.07.007

Borgerson, J. L. (2008). Poetry lessons: on organizing creativity. Aesthesis 2, 4-14. Available online at: https://www.academia.edu/1288641/Poetry_Lessons_On_ Organizing_Creativity (accessed January 15, 2020).

Boud, D., Keogh, R., and Walker, D. (1985). Reflection: Turning Experience into Learning. London: Routledge.

Bradbury, H. (2003). Sustaining inner and outer worlds: a whole-systems approach to developing sustainable business practices in management. J. Manag. Educ. 27, 172-187. doi: 10.1177/1052562903251414

Braun, V., and Clarke, V. (2006). Using thematic analysis in psychology. Qual. Res. Psychol. 3, 77-101. doi: 10.1191/1478088706qp063oa

Britton, J., Burgess, T., Martin, N., McLeod, A., and Rosen, H. (1975). Development of Writing Abilities [11-18]. London: McMillan.

Brown, S. A. (2015). Creative expression of science through poetry and other media can enrich medical and science education. Front. Neurol. 6:3. doi: 10.3389/fneur.2015.00003

Bugeja, M. J. (1994). The Art and Craft of Poetry. Ohio: Writer's Digest Books.

Burns, H. (2011). Teaching for transformation:(Re) designing sustainability courses based on ecological principles. J. Sustain. Educ. 2, 1-15. Available online at: http://www.susted.com/wordpress/content/teaching-for-transformationredesigning-sustainability-courses_2011_03/ (accessed January 15, 2020).

Burns, H., Diamond-Vaught, H., and Bauman, C. (2015). Leadership for sustainability: theoretical foundations and pedagogical practices that foster change. Int. J. Leadersh. Stud. 9, 131-143. Available online at: https:// pdxscholar.library.pdx.edu/cgi/viewcontent.cgi?article=1044\&context=elp_fac (accessed January 15, 2020).

Catanzaro, M. (1988). "Using qualitative analytical techniques," in Nursing Research: Theory and Practice, eds. N. Woods and M. Catanzaro (St. Louis: Mosby Incorporated), 437-456.

Cavanaugh, C. A. (2002). The Aeolian Harp: beauty and unity in the poetry and prose of Ralph Waldo Emerson. Rocky Mountain Rev. Lang. Lit. 56, 25-35. doi: $10.2307 / 1348011$

Chia, R., and Holt, R. (2008). The nature of knowledge in business schools. Acad. Manag. Learn. Educ. 7, 471-486. doi: 10.5465/amle.2008.35882188
Ciardiello, A. V. (2010). "Talking Walls": presenting a case for social justice poetry in literacy education. Read. Teacher 63, 464-473. doi: 10.1598/RT. 63.6 .3

Clark, B., and Button, C. (2011). Sustainability transdisciplinary education model: interface of arts, science, and community (STEM). Int. J. Sustain. Higher Educ. 12, 41-54. doi: 10.1108/14676371111098294

Collett, T. J., and McLachlan, J. C. (2006). Evaluating a poetry workshop in medical education. Med. Human. 32, 59-64. doi: 10.1136/jmh.2005.000222

Colomer, J., Serra, T., Cañabate, D., and Bubnys, R. (2020). Reflective learning in higher education: active methodologies for transformative practices. Sustainability 12:3827.doi: 10.3390/su12093827

Cooper, R. (1990). “Organization/disorganization," in The Theory and Philosophy of Organisations, eds. J. Hassard and P. Dennis (London: Routledge), 167-197.

Daniel, B. K. (2019). "What constitutes a good qualitative research study? Fundamental dimensions and indicators of rigour in qualitative research: the TACT framework" in Kidmore End: Academic Conferences International Limited. European Conference on Research Methodology for Business and Management Studies. doi: 10.34190/RM.19.113

Davis, F. H. (1913). The poetry of Yone Noguchi. Acad. Lit. 85, 5-6.

Dey, P., and Steyaert, C. (2007). The troubadours of knowledge: passion and invention in management education. Organization 14, 437-461. doi: $10.1177 / 1350508407076153$

d'Orville, H. (2019). The relationship between sustainability and creativity. Cadmus 4, 65-73. Available online at: https://www.cadmusjournal.org/node/ 742 (accessed January 15, 2020).

Downe-Wamboldt, B. (1992). Content analysis: method, applications, and issues. Health Care Women Int. 13, 313-321. doi: 10.1080/07399339209516006

Duchi, L., Lombardi, D., Paas, F., and Loyens, S. M. M. (2020). How a growth mindset can change the climate: the power of implicit beliefs in influencing people's view and action. J. Environ. Psychol. 70:101461. doi: $10.1016 /$ j.jenvp.2020.101461

Dunlap, J. C. (2005). Problem-based learning and self-efficacy: how a capstone course prepares students for a profession. Educ. Technol. Res. Dev. 53, 65-83. doi: $10.1007 / \mathrm{BF} 02504858$

Dunlap, J. C. (2006). Using guided reflective journaling activities to capture students' changing perceptions. TechTrends 50, 20-26. doi: 10.1007/s11528-006-7614-x

Dweck, C. S., and Yeager, D. S. (2019). Mindsets: a view from two eras. Perspect. Psychol. Sci. 14, 481-496. doi: 10.1177/17456916188 04166

Eaton, M., Davies, K., Williams, S., and MacGregor, J. (2017). "Why sustainability education needs pedagogies of reflection and contemplation," in Contemplative Approaches to Sustainability in Higher Education: Theory and Practice, eds. M. Eaton, H. J. Hughes, J. MacGregor (London and New York: Routledgee), 3-15. doi: 10.4324/9781315641249-1

Ehrenfeld, J. R. (2009). Sustainability by Design: A Subversive Strategy for Transforming Our Consumer Culture. New Haven: Yale University Press.

Eisner, E. (2008). "Art and knowledge," in Handbook of the Arts in Qualitative Research: Perspectives, Methodologies, Examples, and Issues, eds. J. G. Knowles, and A. L. Cole (California, CA: Sage Publications), 3-12. doi: 10.4135/9781452226545.n1

Eisner, E. W. (2002). The Arts and the Creation of Mind. New Haven: Yale University Press.

Elkington, J. (2018). 25 years ago I coined the phrase "Triple Bottom Line". Here's why it is time to rethink it. Harvard Business Review. Available online at: https://hbr.org/2018/06/25-years-ago-i-coined-the-phrase-triple-bottomline-heres-why-im-giving-up-on-it (accessed July 14, 2021).

Emblen-Perry, K. (2018). Enhancing student engagement in business sustainability through games. Int. J. Sustain. Higher Educ. 19, 858-876. doi: 10.1108/IJSHE-05-2017-0075

Faulkner, S. L. (2020). Poetic Inquiry. Craft, Method and Practice. New York and London: Routledge. doi: 10.4324/9781351044233

Fellows, N. J. (1994). A window into thinking: using student writing to understand conceptual change in science learning. J. Res. Sci. Teach. 31, 985-1001. doi: 10.1002/tea.3660310911

Finch-Race, D. A., and Weber, J. (2015). The ecocritical stakes of french poetry from the industrial era. Dix-Neuf 19, 159-166. doi: $10.1179 / 1478731815 Z .00000000084$ 
Förster, R., Zimmerman, A. B., and Mader, C. (2019). Transformative teaching in higher education for sustainable development: facing the challenges. GAIA 28, 324-326. doi: 10.14512/gaia.28.3.18

Foster, W., and Freeman, E. (2008). Poetry in general practice education: perceptions of learners. Fam. Pract. 25, 294-303. doi: 10.1093/fampra/cmn034

Fraiberg, A. M. (2010). "With edges of rage and despair": anger and the poetry of office life. J. Manag. Inq. 19, 196-207. doi: 10.1177/105649261036 6731

Frisk, E., and Larson, K. L. (2011). Educating for sustainability: competencies and practices for transformative action. J. Sustain. 2, 1-20. Availabe online at: http://www.jsedimensions.org/wordpress/wp-content/uploads/2011/03/ FriskLarson2011.pdf (accessed January 15, 2020).

Furman, R. (2005). Using poetry and written exercises to teach empathy. J. Poet. Ther. 18, 103-110. doi: 10.1080/08893670500140549

Gadamer, H.-G. (1976). Philosophical Hermeneutics. Berkeley: University of California Press.

Garrard, G. (2007). Ecocriticism and education for sustainability. Pedagogy 7, 359-383. doi: 10.1215/15314200-2007-005

Gillis, A. (2001). Journal writing in health education. New Direct. Adult Cont. Educ. 90, 49-58. doi: 10.1002/ace.20

Gladwin, T. N., Kennelly, J. J., and Krause, T. (1995). Shifting paradigms for sustainable development: implications for management theory and research. Acad. Manag. Rev. 20, 874-907. doi: 10.5465/amr.1995.9512 280024

Globally Responsible Leadership Initiative (2012). The 50+20 Agenda. Management Education for the World. Available online at: https://grli. org/initiatives/the-5020-vision/ (accessed July 4, 2021).

Goodman, N. (1976). Languages of Art: An Approach to a Theory of Symbols. Indianapolis, IN: Hackett publishing.

Greenberg, U. E. (2008). The politics of the Walter Benjamin industry. Theory Cult. Soc. 25, 53-70. doi: 10.1177/0263276408090657

Gretzel, U., Davis, E. B., Bowser, G., Jiang, J., and Brown, M. (2014). Creating global leaders with sustainability mindsets-insights from the RMSSN summer academy. J. Teach. Travel Tour. 14, 164-183. doi: $10.1080 / 15313220.2014 .907958$

Grisham, T. (2006). Metaphor, poetry, storytelling and cross-cultural leadership. Manag. Decis. 44, 486-503. doi: 10.1108/00251740610663027

Hanlon, C. (2016). The major prose. New Eng. Q. 89, 153-158. doi: 10.1162/TNEQ_r_00521

Heidegger, M. (1962). Being and Time. New York, NY: Harper and Row.

Hermes, J., and Rimanoczy, I. (2018). Deep learning for a sustainability mindset. Int. J. Manag. Educ. 16, 460-467. doi: 10.1016/j.ijme.2018.08.001

Humphries-Kil, M. (2017). Telling (emotional) stories about managment education. Int. J. Manag. Educ. 15, 384-392. doi: 10.1016/j.ijme.2017. 03.016

Huneke, M. E. (2005). The face of the un-consumer: an empirical examination of the practice of voluntary simplicity in the United States. Psychol. Market. 22, 527-550. doi: 10.1002/mar.20072

Illeris, H. (2012). Interrogations: art, art education and environmental sustainability. Int. J. Educ. Through Art 8, 221-237. doi: 10.1386/eta.8.3.221_1

IPBES (2019). "Global assessment report on biodiversity and ecosystem services of the Intergovernmental Science-Policy Platform on Biodiversity and Ecosystem Services," in eds. E. S. Brondizio, J. Settele, S. Díaz, and H. T. Ngo. Bonn: IPBES secretariat

IPCC (2018). "Summary for Policymakers," in Global Warming of $1.5^{\circ} \mathrm{C}$. An IPCC Special Report on the impacts of global warming of $1.5^{\circ} \mathrm{C}$ above pre-industrial levels and related global greenhouse gas emission pathways, in the context of strengthening the global response to the threat of climate change, sustainable development, and efforts to eradicate poverty, eds. V. Masson-Delmotte, P. Zhai, H.-O. Pörtner, D. Roberts, J. Skea, P. R. Shukla, et al. (Geneva: World Meteorological Organization).

Ivanaj, V., Poldner, K., and Shrivastava, P. (2014). HAND/HEART/HEAD: aesthetic practice pedagogy for deep sustainability learning. J. Corp. Citizensh. 2014, 23-46. doi: 10.9774/GLEAF.4700.2014.ju.00005

Jänicke, M. (2008). Ecological modernisation: new perspectives. J. Clean. Prod. 16, 557-565. doi: 10.1016/j.jclepro.2007.02.011
Kagan, S., and Kirchberg, V. (2016). Music and sustainability: organizational cultures towards creative resilience-a review. J. Clean. Prod. 135, 1487-1502. doi: 10.1016/j.jclepro.2016.05.044

Kalman, C. S. (2020). "Reflective writing in active learning classrooms," in Active Learning in College Science (Cham: Springer), 73-87. doi: 10.1007/978-3-030-33600-4_6

Kassel, K., Rimanoczy, I., and Mitchell, S. F. (2016). The sustainability mindset. connecting being, thinking, and doing in management education. Acad. Manag. Proc. 2016:16659. doi: 10.5465/ambpp.2016.16659abstract

Kostera, M. (1997). Personal performatives: collecting poetical definitions of management. Organization 4, 345-353. doi: 10.1177/1350508497 43003

Kristjánsson, K. (2017). Recent work on flourishing as the aim of education: a critical review. Br. J. Educ. Stud. 65, 87-107. doi: 10.1080/00071005.2016.1182115

Kurylo, B. (2020). Technologised consumer culture: the Adorno-Benjamin debate and the reverse side of politicisation. J. Consum. Cult. 20, 619-636. doi: $10.1177 / 1469540518773819$

Lambrechts, W. (2019). 21st century skills, individual competences, personal capabilities and mind-sets related to sustainability: a management and education perspective. Central Eur. Rev. Econ. Manag. 3, 7-17. doi: $10.29015 /$ cerem. 855

Lambrechts, W. (2021). Learning "for" and "in" the future: on the role of resilience and empowerment in education. Paper commissioned for the UNESCO Futures of Education report (forthcoming, 2021).

Lambrechts, W., Ghijsen, P. W. T., Jacques, A., Walravens, H., Van Liedekerke, L., and Van Petegem, P. (2018b). Sustainability segmentation of business students: toward self-regulated development of critical and interpretational competences in a post-truth era. J. Clean. Prod. 202, 561-570. doi: 10.1016/j.jclepro.2018.07.303

Lambrechts, W., Mul,à, I., Ceulemans, K., Molderez, I., and Gaeremynck, V. (2013). The integration of competences for sustainable development in higher education: an analysis of bachelor programs in management. J. Clean. Prod. 48, 65-73. doi: 10.1016/j.jclepro.2011.12.034

Lambrechts, W., Van Liedekerke, L., and Van Petegem, P. (2018a). Higher education for sustainable development in Flanders: balancing between normative and transformative approaches. Environ. Educ. Res. 24, 1284-1300. doi: 10.1080/13504622.2017.1378622

Lambrechts, W., and Van Petegem, P. (2016). The interrelations between competences for sustainable development and research competences. Int. J. Sustain. Higher Educ. 17, 776-795. doi: 10.1108/IJSHE-03-2015-0060

Le Blanc, D. (2015). Towards integration at last? the sustainable development goals as a network of targets. Sustain. Dev. 23, 176-187. doi: 10.1002/sd.1582

Leech, N. L., and Onwuegbuzie, A. J. (2007). An array of qualitative data analysis tools: a call for data analysis triangulation. School Psychol. Q. 22, 557-584. doi: 10.1037/1045-3830.22.4.557

Leech, N. L., and Onwuegbuzie, A. J. (2008). Qualitative data analysis: a compendium of techniques and a framework for selection for school psychology research and beyond. School Psychol. Q. 23, 587-604. doi: $10.1037 / 1045-3830.23 .4 .587$

Leech, N. L., and Onwuegbuzie, A. J. (2011). Beyond constant comparison qualitative data analysis. School Psychol. Q. 26, 70-84. doi: 10.1037/a0022711

Leggo, C. (2008). “The ecology of personal and professional experience: a poet's view. The ecology of personal and professional experience: a poet's view," in Arts-Based Inquiry in Diverse Learning Communities: Foundations for Practice, eds. M. Cahnmann and R. Siegesmund (Mahwah: Lawrence Erlbaum), 89-97.

Levin, K., Cashore, B., Bernstein, S., and Auld, G. (2012). Overcoming the tragedy of super wicked problems: constraining our future selves to ameliorate global climate change. Policy Sci. 45, 123-152. doi: 10.1007/s11077-0129151-0

Lin, C. I., and Li, Y. Y. (2017). An auto-photographic study of undergraduate students' conceptions of ocean sustainability. Int. J. Sustain. Higher Educ. 18, 554-575. doi: 10.1108/IJSHE-11-2015-0182

Lineberry, H. S., and Wiek, A. (2016). “Art and sustainability," in Sustainability Science, eds. H. Heinrichs, P. Martens, G. Michelsen, A. Wiek (Dordrecht: Springer), 311-324. doi: 10.1007/978-94-017-7242-6_26 
Linzey, A., and Linzey, C. (2018). The Palgrave Handbook of Practical Animal Ethics. The Palgrave Macmillan Animal Ethics Series. London: Palgrave Macmillan. doi: 10.1057/978-1-137-36671-9

Longo, C., Shankar, A., and Nuttall, P. (2017). "It's not easy living a sustainable lifestyle": how greater knowledge leads to dilemmas, tensions and paralysis. J. Bus. Ethics 154, 759-779. doi: 10.1007/s10551-016-3422-1

Lopez, Y. P., Rechner, P. L., and Olson-Buchanan, J. B. (2005). Shaping ethical perceptions: an empirical assessment of the influence of business education, culture, and demographic factors. J. Bus. Ethics 60, 341-358. doi: 10.1007/s10551-005-1834-4

Manring, S. L. (2014). The role of universities in developing interdisciplinary action research collaborations to understand and manage resilient social-ecological systems. J. Clean. Prod. 64, 125-135. doi: 10.1016/j.jclepro.2013.07.010

Marcus, J., Kurucz, E. C., and Colbert, B. A. (2010). Conceptions of the businesssociety-nature interface: implications for management scholarship. Bus. Soc. 49, 402-438. doi: $10.1177 / 0007650310368827$

Mark, A. (2016). Don't organize, mourn: environmental loss and musicking. Ethics Environ. 21, 51-77. doi: 10.2979/ethicsenviro.21.2.03

Matthewman, S. (2010). Teaching secondary English as if the planet matters. London and New York: Routledge. doi: 10.4324/9780203 834534

Mazza, N. (2016). Poetry Therapy: Theory and Practice. London and New York: Routledge. doi: 10.4324/9781315748740

McMullen, B. (2003). Emotional intelligence. BMJ 326, S19-19. doi: $10.1136 / \mathrm{bmj} .326 .7381 . S 19$

Miles, M. B., and Huberman, A. M. (1994). Qualitative Data Analysis: An Expanded Sourcebook (2nd ed.). Thousand Oaks, CA: Sage.

Millan, H. L. (1996). Poetry in engineering education. J. Eng. Educ. 85, 157-162. doi: 10.1002/j.2168-9830.1996.tb00225.x

Mintzberg, H. (2004). Managers Not MBAs: A Hard Look at the Soft Practice of Managing and Management Development (1st ed.). Oakland: BerrettKoehler Publishers.

Molderez, I. (2007). Spirits of ecological thinking. Int. J. Innovat. Sustain. Dev. 2, 376-394. doi: 10.1504/IJISD.2007.017946

Molderez, I., and Ceulemans, K. (2018). The power of art to foster systems thinking, one of the key competencies of education for sustainable development. J. Clean. Prod. 186, 758-770. doi: 10.1016/j.jclepro.2018.03.120

Morgan, C. (2010). What Poetry Brings to Business. Michigan: University of Michigan Press. doi: 10.3998/mpub.187388

Morgan, D. L. (1993). Qualitative content analysis: a guide to paths not taken. Qual. Health Res. 3, 112-121. doi: 10.1177/1049732393003 00107

Morris, J. A., Urbanski, J., and Fuller, J. (2005). Using poetry and the visual arts to develop emotional intelligence. J. Manag. Educ. 29, 888-904. doi: $10.1177 / 1052562905277313$

Mossholder, K. W., Settoon, R. P., Armenakis, A. A., and Harris, S. G. (2000). Emotion during organizational transformations. Group Organ. Manag. 25, 220-243. doi: 10.1177/1059601100253002

Mujtaba, B. G., Cavico, F. J., Nonet, G., Rimanoczy, I., and Samuel, M. (2015). Developing a legal, ethical, and socially responsible mindset for business leadership. Adv. Soc. Sci. Res. J. 2, 9-26. doi: 10.14738/assri.26.1200

Naess, A. (1973). The shallow and the deep, long-range ecology movement. A summary. Inquiry 16, 95-100. doi: 10.1080/00201747308601682

Naess, A. (1990). Ecology, Community and Lifestyle: Outline of an Ecosophy. Cambridge: Cambridge University Press. doi: 10.1017/CBO97805115 25599

Nejati, M., and Nejati, M. (2013). Assessment of sustainable university factors from the perspective of university students. J. Clean. Prod. 48, 101-107. doi: $10.1016 /$ j.jclepro.2012.09.006

Ng, E. S., and Burke, R. J. (2010). Predictor of business students' attitudes toward sustainable business practices. J. Bus. Ethics 95, 603-615. doi: 10.1007/s10551-010-0442-0

Norton, B. G. (1991). Toward Unity Among Environmentalists. New York: Oxford University Press.

Nussbaum, M. C. (1998). Cultivating Humanity: A Classical Defense of Reform in Liberal Education. Cambridge: Harvard University Press. doi: $10.2307 /$ j.ctvjghth8
Nussbaum, M. C. (2010). Not for Profit: Why Democracy Needs the Humanities. Princeton University Press.

Nussbaum, M. C. (2011). Creating Capabilities. The Human Development Approach. Cambridge/London: The Belknap Press of Harvard University Press. doi: 10.4159/harvard.9780674061200

Painter, M., Hibbert, S., and Cooper, T. (2019). The development of responsible and sustainable business practice: value, mind-sets, business-models. J. Bus. Ethics 157, 885-891. doi: 10.1007/s10551-018-3958-3

Parkes, C., Buono, A. F., and Howaidy, G. (2017). The principles for responsible management education (PRME): the first decade-what has been achieved? the next decade-responsible management education's challenge for the sustainable development goals (SDGs). Int. J. Manag. Educ. 15, 61-65. doi: 10.1016/j.ijme.2017.05.003

Paulus, T. M., and Lester, J. N. (2016). ATLAS.ti for conversation and discourse analysis studies. Int. J. Soc. Res. Methodol. 19, 405-428. doi: 10.1080/13645579.2015.1021949

Pennebaker, J. W., Mehl, M. R., and Niederhoffer. (2003). Psychological aspects of natural language use: our words, our selves. Annu. Rev. Psychol. 54, 547-577. doi: 10.1146/annurev.psych.54.101601.145041

Pixley, J. (2004). Emotions in Finance. Distrust and Uncertainty in Global Markets. Cambridge: Cambridge University Press. doi: 10.1017/CBO9781139195041

Prendergast, M. (2009). “'Poem is what?”: poetic inquiry in qualitative social science research," in Poetic Inquiry: Vibrant Voices in the Social Sciences, eds. M. Prendergast, C. Leggo, and P. Sameshima (Rotterdam: Sense Publishers), xix-xli. doi: 10.1163/9789087909512

Raelin, J. A. (2002). "I Dont Have Time to Think!" versus the art of reflective practice. Reflections 4, 66-79. Availabe online at: https://www.researchgate.net/ publication/240275477_I_Don't_Have_Time_to_Think_versus_the_Art_of_ Reflective_Practice (accessed January 15, 2020).

Raivio, K. (2011). Sustainability as an educational agenda. J. Clean. Prod. 19, 1906-1907. doi: 10.1016/j.jclepro.2011.07.009

Rangel, N. (2016). An examination of poetry for the people: a decolonizing holistic approach to arts education. Educ. Stud. 52, 536-551. doi: 10.1080/00131946.2016.1231680

Ransome, A. (1910). The poetry of Yone Noguchi. Fortnight. Rev. 88, 527-533.

Reale, M. (2015). "We never thought it would be like this": refugees' experiences in Sicily. Qual. Rep. 20, 107-114. doi: 10.46743/2160-3715/2015.1823

Reason, P. (2007). Education for ecology: science, aesthetics, spirit and ceremony. Manag. Learn. 38, 27-44. doi: 10.1177/1350507607073021

Reid, J., Carpenter, D., and Meehan, B. (2006). "Art for earth's sake: creative and interdisciplinary collaborations for sustainability in the tertiary sector," in Sustainability in the Australasian University Context, eds. W. L. Filho and D. Carpenter, 81-90.

Remington, S. M., Hiller Connell, K. Y., Armstrong, C. M., and Musgrove, S. (2013). Assessing sustainability education in a transdisciplinary undergraduate course focused on real-world problem solving. Int. J. Sustain. Higher Educ. 14, 404-433. doi: 10.1108/IJSHE-01-2012-0001

Reyers, B., and Selig, E. R. (2020). Global targets that reveal the social-ecological interdependencies of sustainable development. Nat. Ecol. Evol. 4, 1011-1019. doi: 10.1038/s41559-020-1230-6

Richards, L., and Morse, J. M. (2012). Readme First for a User's Guide to Qualitative Method. London: Sage.

Rieckmann, M. (2012). Future-oriented higher education: which key competencies should be fostered through university teaching and learning? Futures 44, 127-135. doi: 10.1016/j.futures.2011.09.005

Rimanoczy, I. (2014). A matter of being. Developing sustainability-minded leaders. J. Manag. Global Sustain. 2, 95-122. doi: 10.13185/JM2014.02105

Rogers, R. (2001). Reflection in higher education: a concept analysis. Innov. High. Educ. 26, 37-56. doi: 10.1023/A:1010986404527

Ryman, J. A., Porter, T. W., and Galbraith, C. S. (2009). Disciplined imagination: art and metaphor in the business school classroom. Int. J. Educ. Arts 10, 1-25. Availabe online at: https://files.eric.ed.gov/fulltext/EJ859041.pdf (accessed January 15, 2020).

Sanchez-Burks, J., and Huy, Q. N. (2009). Emotional aperture and strategic change: the accurate recognition of collective emotions. Organ. Sci. 20, 22-34. doi: $10.1287 /$ orsc. 1070.0347

Sandri, O. J. (2013). Threshold concepts, systems and learning for sustainability. Environ. Educ. Res. 19, 810-822. doi: 10.1080/13504622.2012.753413 
Sauerwein, M., Karana, E., and Rognoli, V. (2017). Revived beauty: research into aesthetic appreciation of materials to valorise materials from waste. Sustainability 9:529. doi: 10.3390/su9040529

Scales, B. J. (2012). Qualitative analysis of student assignments: a practical look at ATLAS.ti. Ref. Serv. Rev. 41, 134-147. doi: 10.1108/009073213113 00956

Schneider, S. C., Zollo, M., and Manocha, R. (2010). Developing socially responsible behaviour in managers. J. Corp. Citizensh. 2010, 21-40. doi: 10.9774/GLEAF.4700.2010.au.00004

Schwartz, S., Cieciuch, J., Vecchione, M., Davidov, E., Fischer, R., Beierlein, C., et al. (2012). Refining the theory of basic individual values. J. Personal. Soc. Psychol. 103, 663-688. doi: 10.1037/a00 29393

Schwartz, S. H. (1992). "Universals in the content and structure of values: theory and empirical tests in 20 countries," in Advances in Experimental Social Psychology (Vol. 25), eds. M. Zanna (New York, NY: Academic Press), 1-65. doi: 10.1016/S0065-2601(08)60281-6

Shephard, K. (2008). Higher education for sustainability: seeking affective learning outcomes. Int. J. Sustain. Higher Educ. 9, 87-98. doi: $10.1108 / 14676370810842201$

Shrivastava, P. (2010). Pedagogy of passion for sustainability. Acad. Manag. Learn. Educ. 9, 443-455. doi: 10.5465/AMLE.2010.53791826

Shrivastava, P., Ivanaj, V., and Ivanaj, S. (2012). Sustainable development and the arts. Int. J. Technol. Manag. 60:23. doi: 10.1504/IJTM.2012. 049104

Sipos, Y., Battisti, B., and Grimm, K. (2008). Achieving transformative sustainability learning: engaging head, hands and heart. Int. J. Sustain. Higher Educ. 9, 68-86. doi: 10.1108/14676370810842193

Small, C. (1998). Musicking: The Meanings of Performing and Listening. Connecticut: Wesleyan University Press.

Smilor, R. W. (1997). Entrepreneurship: reflections on a subversive activity. J. Bus. Ventur. 12, 341-346. doi: 10.1016/S0883-9026(97)00008-6

Smith, M. (2001). Environmental Anamnesis: Walter Benjamin and the ethics of extinction. Environ. Ethics 23, 359-76. doi: 10.5840/enviroethics200 12343

Smollan, R. K. (2006). Minds, hearts and deeds: cognitive, affective and behavioural responses to change. J. Change Manag. 6, 143-158. doi: 10.1080/14697010600725400

Sterling, S. (2011). Transformative learning and sustainability: sketching the conceptual ground. Learn. Teach. Higher Educ. 5, 17-33. Available online at: https://www.researchgate.net/publication/266184629_Transformative _ Learning_and_Sustainability_Sketching_the_Conceptual_Ground/link/ 6059b7ad299bf1736760fde4/download (accessed July 14, 2021).

Sterling, S., and Thomas, I. (2006). Education for sustainability: the role of capabilities in guiding university curricula. Int. J. Innov. Sustain. Dev. 1:349. doi: 10.1504/IJISD.2006.013735

Svanström, M., Lozano-García, F. J., and Rowe, D. (2008). Learning outcomes for sustainable development in higher education. Int. J. Sustain. Higher Educ. 9, 339-351. doi: 10.1108/14676370810885925

Taylor, S. S., and Ladkin, D. (2009). Understanding arts-based methods in managerial development. Acad. Manag. Learn. Educ. 8, 55-69. doi: 10.5465/amle.2009.37012179

Toms, M., and Toms, J. (1999). True Work: Doing What You Love and Loving What You Do. New York, NY: Harmony.

Treacy, D., and Gaunt, H. (2021). Promoting interconnections between reflective practice and collective creativity in higher arts education: the potential of engaging with a reflective matrix. Reflect. Pract. 22, 488-500. doi: $10.1080 / 14623943.2021 .1923471$

UNESCO (2006). Road Map for Arts Education. Available online at: http://www. unesco.org/new/fileadmin/MULTIMEDIA/HQ/CLT/CLT/pdf/Arts_Edu_ RoadMap_en.pdf (accessed January 15, 2020).

UNESCO (2010). Seoul Agenda: Goals for the Development of Arts Education. Available online at: http://www.unesco.org/new/fileadmin/MULTIMEDIA/ HQ/CLT/CLT/pdf/Seoul_Agenda_EN.pdf (accessed January 15, 2020).

United Nations (2000). United Nations Millennium Declaration. General Assembly resolution $55 / 2$ of 8 September 2000. https://www.ohchr.org/ EN/ProfessionalInterest/Pages/Millennium.aspx\#:|sim:text=\%20United \%20Nations\%20Millennium\%20Declaration $\% 20 \% 201 \% 20 \mathrm{We} \% 2 \mathrm{C}$, of $\% 20$ the
\%20Charter\%20of\%20the\%20United...\%20More\%20 (accessed January 15, 2020).

United Nations (2015). Transforming our world: the 2030 Agenda for Sustainable Development. Resolution adapted by the General Assembly. United Nations Publications, New York. doi: 10.18356/4523 8899-en

van Boeckel, J. (2014). At the heart of art and earth: an exploration of practices in arts-based environmental education. Environ. Educ. Res. 21, 801-802. doi: 10.1080/13504622.2014.9 59474

Van den Bergh, J. C. J. M. (2010). Externality or sustainability economics? Ecol. Econ. 69, 2047-2052. doi: 10.1016/j.ecolecon.2010. 02.009

Vandertop, C. (2016). The colonies in concrete. Walter Benjamin, urban form and the dreamworlds of empire. Interventions 18, 709-729. doi: 10.1080/1369801X.2015.1131183

Victor, D. G., Akimoto, K., Kaya, Y., Yamaguchi, M., Cullenward, D., and Hepburn, C. (2017). Prove Paris was more than paper promises. Nature 548, 25-27. doi: $10.1038 / 548025$ a

Wagner, C. (1901). The Simple Life. New York, NY: Grosset and Dunlop.

Wall, T. (2016a). Author Response: provocative education: from the Dalai Lama's Cat $(\mathrm{B}$ to Dismal Land ( $)$. Stud. Philos. Educ. 35, 649-653. doi: $10.1007 / \mathrm{s} 11217-016-9521-8$

Wall, T. (2016b). Reviving the ubuntu spirit in landscapes of practice: evidence from deep within the forest. J. Work-Appl. Manag. 8, 95-98. doi: 10.1108/JWAM-10-2016-0018

Wall, T., Clough, D., Österlind, E., and Hindley, A. (2019a). "Conjuring A 'Spirit' for Sustainability: a review of the socio-materialist effects of provocative pedagogies," in Sustainability and the Humanities, eds. W. L. Filho and A. C. McCrea (Cham: Springer), 313-327. doi: 10.1007/978-3-319-95336-6_17

Wall, T., and Jarvis, M. (2015). Business Schools as Educational Provocateurs of Productivity via Interrelated Landscapes of Practice. CABS Leadership and Policy Paper.

Wall, T., Österlind, E., and Fries, J. (2019b). "Arts based approaches for sustainability," in Encyclopedia of Sustainability in Higher Education, ed. W. L. Filho (Cham: Springer Nature). doi: 10.1007/978-3-030-11352-0_523

Walshe, N. (2013). Exploring sustainable development through poetry and moving image. Teach. Geogr. 38, 119-121. Availabe online at: https://www.academia. edu/8575892/Exploring_sustainable_development_through_poetry_and_ moving_image (accessed January 15, 2020).

Walshe, N. (2017). An interdisciplinary approach to environmental and sustainability education: developing geography students' understandings of sustainable development using poetry. Environ. Educ. Res. 23, 1130-1149. doi: 10.1080/13504622.2016.1221887

Walther, C. S., and Sandlin, J. A. (2013). Green capital and social reproduction within families practising voluntary simplicity in the US. Int. J. Consum. Stud. 37, 36-45. doi: 10.1111/j.1470-6431.2011.01050.x

Warburton, K. (2003). Deep learning and education for sustainability. Int. J. Sustain. Higher Educ. 4, 44-56. doi: 10.1108/146763703104 55332

Washington, H., Taylor, B., Kopnina, H., Cryer, P., and Piccolo, J. J. (2017). Why ecocentrism is the key pathway to sustainability. Ecol. Citizen 1, 35-41.

Werhane, P. (2008). Mental models, moral imagination and system thinking in the age of globalization. J. Bus. Ethics, 78, 463-474. doi: 10.1007/s10551-006-9338-4

Werhane, P., Hartman, L., Archer, C., Englehardt, E., and Pritchard, M. (2013). Obstacles to Ethical Decision-Making: Mental Models, Milgram and the Problem of Obedience. Cambridge: Cambridge University Press. doi: 10.1017/CBO9780511675911

White, R. (2017). Walter Benjamin: "The Storyteller" and the possibility of wisdom. J. Aesthetic Educ. 51, 1-14. doi: 10.5406/jaesteduc.51.1.0001

Wiek, A., Withycombe, L., Redman, C. L. (2011). Key Competencies in Sustainability: a Reference Framework for Academic Program Development. Sustainability Science 6, 203-218.

Wilson, B. G., Parrish, P., and Veletsianos, G. (2008). Raising the bar for instructional outcomes: toward transformative learning experiences. Educ. Technol. 48, 39-44. Availabe online at: https://www.academia.edu/324597/ Raising_the_Bar_for_Instructional_Outcomes_Toward_Transformative Learning_Experiences (accessed January 15, 2020). 
Wilson, B. G., Switzer, S. H., Parrish, P., and the IDEAL Research Lab (2006). "Transformative learning experiences: how do we get students deeply engaged for lasting change?" in Proceedings of Selected Research and Development Presentations, eds. M. Simonson (Bloomington, IN: Association for Educational Communications and Technology). Available online at: https://members.aect. org/pdf/Proceedings/proceedings06/2006I/06_63.pdf (accessed 14 July, 2021).

Windle, R. (1994). The Poetry of Business Life: An Anthology. Oakland: BerrettKoehler Publishers.

Wolff, B., Mahoney, F., Lohiniva, A. L., and Corkum, M. (2019). "Collecting and analyzing qualitative data," in The CDC Field Epidemiology Manual, eds. S. A. Rasmussen and R. A. Goodman. doi: 10.1093/oso/9780190933692.0 03.0010

Wolters, F. J., and Wijnen-Meijer, M. (2012). The role of poetry and prose in medical education: the pen as mighty as the scalpel? Perspect. Med. Educ. 1, 43-50. doi: 10.1007/s40037-012-0008-1

Yeager, D. S., and Dweck, C. S. (2012). Mindsets that promote resilience: when students believe that personal characteristics can be developed. Educ. Psychol 47, 302-314. doi: 10.1080/00461520.2012.722805
Conflict of Interest: The authors declare that the research was conducted in the absence of any commercial or financial relationships that could be construed as a potential conflict of interest.

Publisher's Note: All claims expressed in this article are solely those of the authors and do not necessarily represent those of their affiliated organizations, or those of the publisher, the editors and the reviewers. Any product that may be evaluated in this article, or claim that may be made by its manufacturer, is not guaranteed or endorsed by the publisher.

Copyright @ 2021 Molderez, Baraniuk and Lambrechts. This is an open-access article distributed under the terms of the Creative Commons Attribution License (CC BY).

The use, distribution or reproduction in other forums is permitted, provided the original author(s) and the copyright owner(s) are credited and that the original publication in this journal is cited, in accordance with accepted academic practice. No use, distribution or reproduction is permitted which does not comply with these terms. 